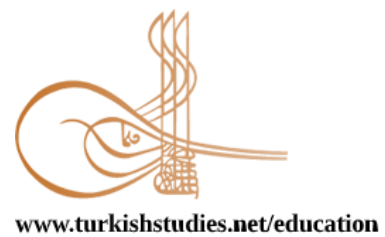

Turkish Studies - Educational Sciences

\title{
8. Sınıf Türkçe Ders Kitabındaki (MEB, 2019) Cümle Bilgisi Etkinliklerine Eleştirel Bir Bakış
}

\author{
A Critical Point Of View Aiming At Sentence Knowledge Activities In 8th Grade Turkish Text Book \\ (MEB Press, 2019)
}

\author{
Gülşah Durmuş*
}

\begin{abstract}
The aim of this study is to determine the sentence information activities for the process of reading and listening/ monitoring texts in eight themes in Primary Turkish 8 Lessons Book (MEB Press, 2019) interpret and evaluate them with a critical perspective. In the study, scanning model, which is one of the descriptive research patterns, was used. In the book examined at the end of the study, it was determined that the activities shaped around the main and auxiliary elements of the sentence field, the main and auxiliary elements of the sentence such as sentence types according to meaning (positive, negative, question), place of predicate (canonical, transpose), type (noun and verb sentence) and structure (single predicate, multi-predicate, verbial, conjunction); phrases (noun clauses, adjective clauses, verb and verb groups, etc.); idioms, proverbs and phrases that can be evaluated in a phrase or sentence structure; purpose according to its subject (active, passive) and object (transitive, intransitive), meaning in sentence [(positive, negative, question, subjective and objective judgment; object- result, cause- effect sentences] and emotion (reproach, longing, sadness, regret, exaggeration, surprise, liking); expression disorders, contribution of the arts of speech to the meaning of the sentence, transition and connection expressions that establish meaning relations between sentences etc. spread over a wide range in terms of the sentence information. At the end of the study, it was proposed to update and enrich the sentence information activities in 8th gradeTurkish text book in the light of academic studies focused on grammar teaching processes, especially with the discovery learning in constructive approach carried out in the literature.
\end{abstract}

Structured Abstract: Aim of the Research: The aim of this study is to determine, interpret and critically evaluate sentence information activities for the process of reading and listening/ monitoring texts in eight themes in 8th Grade Turkish Lesson Book (MEB Press, 2019).

\section{Research Method}

Descriptive method, one of the qualitative research methods, was used in the research. "Descriptive studies were carried out to illuminate a given situation, make evaluations in line with standards and reveal possible relationships between events" (Çepni, 2009). The study was carried out in the screening model (Büyüköztürk, 2010, p. 21), which is one of the descriptive research types. "Screening models are research approaches that aim to describe a situation that exists in the past or still as it exists. The event, individual or

\footnotetext{
* Dr. Öğr. Üyesi, İstanbul Aydın Üniversitesi, Eğitim Fakültesi, Türkçe Öğretmenliği Programı Asst. Prof. Dr., İstanbul Aydin University, Education Faculty, Turkish Education Department ORCID 0000-0001-7469-3864 gulsahdurmus@aydin.edu.tr
}

Cite as/ Atıf: Durmuş, G. (2020). 8. sınıf Türkçe ders kitabındaki (MEB, 2019) cümle bilgisi etkinliklerine eleştirel bir bakış. Turkish Studies - Education, 15(4), 2567-2598. https://dx.doi.org/10.47423/TurkishStudies.42837

Received/Geliş: 10 April/Nisan 2020

Accepted/Kabul: 27 August/Ağustos 2020

Checked by plagiarism software

Copyright (C) INTAC LTD, Turkey

Published/Yayın: 30 August/Ağustos 2020

CC BY-NC 4.0 
object that is the subject of the research was tried to be defined in its own conditions and as it is. No effort was made to change or influence them in any way. Th thing aimed to be known existis and it is there. The important thing is to be able to observe and determine it appropriately"(Karasar, 1994, p. 77).

\section{Examined Documents of the Research}

In the research, 8th Grade Turkish Lesson Book (MEB Press, 2019) was accepted as document and sentence information activities in these books were examined.

\section{Data Collection and Analysis}

During the data collection process, all the activities that were created for sentence information in the book accepted as documents were determined and recorded, and during the analysis of the data obtained, these activities were interpreted in the light of the data presented by the literature in the 2019 Turkish Lesson Curriculum and sentence information. It was tried to be revealed that it can be evaluated within the context of sentence information. In this process, the issue of how these events can be updated in the light of current data in the literature was also mentioned, and in the conclusion part of the study, additions were made in the light of the data of the researchers who put forward their views on teaching grammar with a constructivist approach.

After all these explanations, determination and critical of sentence information activities which are formed for the processing processes of reading and listening/ monitoring texts in eight themes in 8th Grade Turkish Lesson Book (MEB Press, 2019) the process of interpretation and evaluation with a view can be started. In this process, the gains and explanations that can be evaluated within the context of sentence information in 2019 Turkish Lesson Curriculum were used as a guiding criterion. The books published in 2019 were examined in the study.

As stated by Güneş, constructivist approach is applied in language teaching in most countries in the world. In accordance with this approach, new grammar, skill and effectiveness approach, induction model and intuition method are used in grammar teaching. Grammar is not considered as a separate lesson but is considered to take place in language learning areas. With the intuition method, emphasis is placed not on memorizing the abstract rules of language, but on developing the language and mental skills of the student. It is aimed to learn the language rules by exploring them with various experimental activities such as scientific information. They are expected to learn the functions, rules and logic of the language and use them in reading and writing studies. In grammar teaching with intuition method, presentation is carried out in six stages. Presentation, observing the event, creating rules and hypotheses, practicing and transferring to the application (Güneş, 2013, p. 17).

At the stage of presentation, teacher examines grammatical events with students with various questions, makes and let students make spelling and corrections related to the event, discusses the problems of comprehension, enables students to understand the importance of grammar, and activates the prior knowledge of students about the grammar event discussed (Güneş, 2013, p. 180, 183 ).

At the stage of observing the event, teacher invites students to recognize the concept of grammar in the texts they read and to observe the events (Güneş, 2013, p. 180, 183).

In the step of changing samples and creating hypotheses, s/he asks students to classify according to their own criteria, observes and notes the processes they use, invites them to form hypotheses about the functions of the event, discusses the hypotheses with the students, teaches the necessary grammar changes according to the need (Güneş, 2013, p. 181, 183).

In the validation of hypothesis step, s/he invites students to use appropriate language changes to verify the applicability of their hypotheses in other texts (Güneş, 2013, p. 181, 183).

In the rule-making step, students are asked to create precise rules and to examine and evaluate them in source grammar books (Güneş, 2013, p. 181, 183).

In the step of doing exercises, s/he plans activities and gives them these activities so that students learn new information (Güneş, 2013, pp. 182- 183).

In the step of transferring to application, s/he controls the event to improve what has been learned in the text writing process (Güneş, 2013, pp. 182-183). 
When all above mentioned steps are evaluated together, it can be observed that there is a wide variety in terms of subject scope that can be included in the sentence knowledge field of sentence information activities in the 8th Grade Turkish Lesson Book (MEB Press, 2019).

However it can be suggected that the books to be prepared in the future should be updated and enriched by taking the opinions stated by Sağır and Demir Atalay (2016) and Aslan (2017) and especially by the the discovery learning in constructive approach carried out in the literature, steps of which are explained in detail by Güneş (2013a, 2013b, 2013c) and the six basic stages of grammer teaching process.

Keywords: Sentence Knowledge Activities; 8th Grade Turkish Lesson Book, Grammar Teaching with The Discovery Learning Method in Constructive Approach.

Öz: Bu çalışmanın amacı, 8. Sınıf Türkçe Ders Kitabı'ndaki (MEB, 2019) sekiz temada yer alan okuma ve dinleme/ izleme metinlerinin işleniş süreçlerine yönelik oluşturulmuş cümle bilgisi etkinliklerinin tespit edilmesi ve eleştirel bir bakışla yorumlanıp değerlendirilmesidir. Çalışmada betimsel araştırma desenlerinden tarama modeli kullanılmıştır. Çalışma sonunda incelenen kitaplarda cümlenin ana ve yardımcı ögeleri; anlamına (olumlu, olumsuz, soru), yükleminin yerine (kurallı, devrik), türüne (isim ve fiil cümlesi) ve yapısına (tek yüklemli, çok yüklemli, fiilimsi ve bağlaç bulunan cümle) göre cümle çeşitleri; sözcük grupları (isim tamlamaları, sıfat tamlamaları, fiilimsiler ve fiilimsi grupları vb.); birer sözcük grubu ya da cümle yapılanışında değerlendirilebilecek deyimler, atasözleri ve kalıp sözler; öznesine (etken, edilgen) ve nesnesine (geçişli, geçişsiz) göre fiil çatıları, cümlede anlam (olumlu, olumsuz, soru, öznel ve nesnel yargı, amaç- sonuç, sebep- sonuç) ve duygu (sitem, özlem, üzülme, pişmanlık, abartma, şaşırma, beğenme); anlatım bozuklukları, söz sanatlarının cümle anlamına olan katkısı, cümleler arası anlam ilişkileri kuran geçiş ve bağlantı ifadeleri vb. konuları etrafinda şekillenen etkinliklerin cümle bilgisi alanı açısından geniş bir yelpazeye yayıldığı tespit edilmiştir. Çalışma sonunda 8. Sınıf Türkçe Ders Kitabında yer alan cümle bilgisi etkinliklerinin alanyazında gerçekleştirilen yapılandırmacı yaklaşım ile özellikle de sezdirme yöntemiyle dil bilgisi öğretim süreçlerine odaklanılan akademik çalışmalar ışığında güncellenmesi ve zenginleştirilmesi teklif edilmiştir.

Anahtar Kelimeler: Cümle Bilgisi Etkinlikleri; 8. Sınıf Türkçe Ders Kitabı, Sezdirme Yöntemiyle Dil Bilgisi Öğretimi.

\section{Giriş}

Gramer, insan [zihnindeki] düşünceyi söze ve söz bütününe dönüştüren dili, bilimsel ölçüler içinde anlatan, o dilin anlaşılması ve kullanılması için gerekli yöntem ve kuralları bir sistem yapısı içinde öğreten bilim dalıdır. Sözlük ve gramerler, dili kuşaklar arasında unutulmaktan kurtaran, onları birbirine bağlayan bağlardır. Gramer, aynı zamanda bir dilin sağlıklı olarak gelişmesinin de anahtarıdır. O dili konuşan toplumun kültür varlığının korunmasında ve sağlıklı bir biçimde yol alışında başlıca etkendir (Korkmaz, 2014, s. 86). Gramer; aynı zamanda [b]ir dilin seslerini, sözcük türlerini, bunların yapılarını, tümce olarak dizilmelerini ve tümce içindeki görevlerini, çekimleriyle ilgili kurallarını inceleyen bir dil bilimi dalıdır. Dillerin genel olarak nasıl oluştuğunu, evrimlerini, dil olaylarını inceleyen bilim ise dil bilim adını alır. Her dilin kendine özgü kuralları bulunduğu için ayrı bir dil bilgisi vardır (Göğüş, 1978, s. 337).

Batı Türkçesinin grameri üzerinde durduğu kitabı Türk Dil Bilgisi'nde Ergin'e göre bir dili bütün cepheleriyle inceleyen bilgi kolu olan dil bilgisinin dilin seslerini inceleyen kısmına ses bilgisi (fonetik), kelime ve şekillerin yapısını inceleyen kısmına şekil bilgisi (morfoloji), kelime ve şekillerin kökenini araştıran kısmına köken/ menşe bilgisi yahut türeme bilgisi (etimoloji), kelime ve şekillerin mânâları üzerinde duran kısmına mânâ bilgisi (semantik), kelime ve şekillerin birbirleriyle olan ilişkilerini ve cümleleri inceleyen kısmına ise cümle bilgisi (sentaks) adı verilir. Dil bilgisinin vazifesi; seslerden cümleye kadar bütün dil birliklerini yapı, mânâ ve vazife bakımından incelemektir. Dil bilgisi çözümlemelerinde de klasik bölümlemelerden ziyade yapı, mânâ ve vazife ölçütlerinin esas alınması daha yerinde olacaktır (Ergin, 2013, s. 28). 
Alanyazında cümle üzerine pek çok tanım yapılmış ve cümle bilgisinin kapsamı konusunda farklı değerlendirmelerde bulunulmuştur. "Cümle, çeşitli duyguların düşüncelere dönüştürüldüğü, anlamlı söz birimlerinin bir yargı bildirecek biçimde birtakım kurallara bağlı olarak bir araya getirildiği dizidir. Kelimeler, kelime grupları, yardımcı ögeler, birtakım kurallara bağlı olarak cümlede yer aldığında ve ekler yapıya uygun bir biçimde bunlara bağlandığında anlamlı bir ifade doğar" (Zülfikar, 2010, s. 202, 207). Burada duyguların düşüncelere dönüştürülmesi, anlamlı söz birimleri, yargı bildirme, kurallara bağlılık açar sözleri etrafında şekillenen bir cümle tanımı yapılmış ve kelimeler, kelime grupları, yardımcı ögeler, süreç boyunca işletilen belirli kurallar ve kullanılan ekler; cümle bilgisi kapsamına dâhil edilmiştir.

Karahan'a göre ise “[c]ümle bilgisinin bir başka ifade ile 'söz dizimi'nin konusu, yargısız bir anlatım birimi olan kelime grupları ile yargılı bir anlatım birimi olan cümlenin yapısı, işleyişi, görevleri ve anlam özellikleridir. Cümlelerin bağlanma şekilleri ile bağlanan cümleler arasındaki şekil ve anlam iliş̧kileri de söz diziminin konusudur" (Karahan, 2018, s. 9).

Karadüz tarafından sözcük öbekleri/ kelime gruplar, cümlenin ögeleri ve farkl türdeki cümlelerin; cümle bilgisi öğretimi sürecinde etkinliklere yansitılan temel konu başlıkları olduğu belirtilmiş ve bu süreçte dikkat edilmesi gereken hususlar vurgulanmıştır: "Cümle bilgisi öğretiminde dildeki sözcük öbekleriyle cümleyi oluşturan ögelerin, farklı türdeki cümlelerin öğretim etkinlikleri üzerinde durulur. Cümle bilgisi çalışmalarında uygulamalara yer vermek; dilin işleyişini, dizgesel dokusunu sezdirmek bakımından önemlidir. Cümleyi tanıtmak için cümleyi tanımlamak gerekmez; cümle kurmak, birbirinden farklı cümleler oluşturarak öğrenenlerin kendi tanımlarına ve bilgilerine ulaşmalarına firsat vermek gerekir. Öğrenci, buna dili oluşturan her türlü malzemeyi kullanarak, yerlerini değiştirerek, kendine ait kanaat elde ederek ulaşabilir" (Karadüz, 2009, s. 306- 307). Aslında cümle; bir fikri, bir düşünceyi, bir hareketi, bir duyguyu, bir hadiseyi tam olarak bir hüküm hâlinde ifade eden kelime grubudur. Kelime grupları, belirtme grupları iken cümle bir hüküm grubudur. Cümlenin temel fonksiyonu bir hüküm ifade etmektir. Onun için cümle; en tam, en geniş kelime grubudur (Ergin, 2013, s. 398). Cümle düzeyinde ele alınan anlatım bozuklukları da [eksiklik, fazlalık, sıra yanlışlığı, uyumsuzluk vb. (Ercilasun, 2010, s. 294- 296)] cümle bilgisinin inceleme alanına dâhil edilmesi gereken konulardan biri olarak belirtilebilir.

Nesneleri ve hareketleri daha geniş olarak ifade etmek ve belirtmek için birden fazla kelimeyi kullanarak meydana getirilen dil birliğine 'kelime grubu/ [sözcük öbeği]' denir (Ergin, 2013, s. 374- 375). Kelime grubunun yapısında ve manasında bir bütünlük vardır. Cümle içinde bir bütün olarak değerlendirilirler. Cümlenin içinde tek bir kelime gibi çekime girerler. İşletme ekleriyle diğer kelimelere veya kelime gruplarına bağlanırlar. Kelime grupları, birer 'belirtme grupları'dır. Nesne ve hareketleri karşılamak için yan yana gelen kelimeler, 'belirten- belirtilen', 'tamlayan- tamlanan', 'tâbi olan- tâbi olunan', 'asıl- yardımcı' olmak üzere iki kısım hâlindedir (Karaörs, 1993, s. 1). Cümle; bir yarg1, bir 'hüküm' grubudur. Cümleden küçük kelime grupları ise birer 'belirtme grubu'durlar (Ergin, 2013, s. 398). Cümlenin varlığı için bir çekimli fiil yeterlidir. Tek kelimelik cümleler, bir çekimli fiille yapılan cümlelerdir. Hüküm, zaman ve şahıs kavramı bir kelimede ifade edilebilir: gideceğim (Karaörs, 1993, s. 36).

Etkinliklerle cümle bilgisi öğretimi süreçlerine hâlihazırdaki Türkçenin eğitimi ve öğretimi açısından bakıldığında 2019 Türkçe Dersi Öğretim Programı'nda cümle bilgisi kapsamında değerlendirilebilecek kazanım ve açıklamaların, 8. sınıf düzeyinde ele alındığı görülmektedir. Çalışmanın bu bölümünde bu programda tespit edilen ve bu çalışma kapsamında incelenen ders kitabında etkinlik çözümlemeleri gerçekleştirilirken göz önünde bulundurulan kazanım ve açıklamalara değinmek yerinde olacaktır.

$\mathrm{Bu}$ kazanımlardan ilk ikisi, programda 8. sınıf "Okuma Becerisi/ Söz Varlığı" alt başlığında yer verilen "T.8.3.5. Bağlamdan yararlanarak bilmediği kelime ve kelime gruplarının anlamını tahmin eder. a) Öğrencilerin tahmin ettikleri kelime ve kelime grupların ögrenmek için sözlük, atasözleri ve deyimler sözlüğü vb. araçları kullanmaları sağlanır. b) 
Öğrencinin öğrendiği kelime ve kelime gruplarından sözlük oluşturması teşvik edilir" ve "T.8.3.6. Deyim, atasözü ve özdeyişlerin metne katkısını belirler" (MEB, 2019, s. 48) kazanım ve açıklamalarıdır. Kelime grupları, alanyazında cümle bilgisi alanı kapsamında değerlendirilen konu başlıklarından biri olduğundan; deyim, atasözü ve özdeyişler ise; yapılanış olarak kelime grubu ya da cümle kuruluşunda oluşları ve anlam bakımından taşıdıkları yoğun, soyut, mecaza dayalı ve üst düzey yansılarıyla bu çalışmada cümle bilgisi kapsamında ele alınması gereken konulardan biri olarak değerlendirilmiştir.

Programda aynı alt başlıkta yer alan bir diğer kazanım ve bu kazanıma ait açıklama ifadeleri şu şekildedir: "T.8.3.7. Metindeki söz sanatlarını tespit eder. Benzetme (teşbih), kişileştirme (teşhis), konuşturma (intak) ve karşıtllı (tezat), abartma (mübalağa) söz sanatlarının belirlenmesi sağlanır" (MEB, 2019, s. 48). Cümleye, taşındığı yapı birimleri ile yeni anlam boyutları kazandıran söz sanatları, bu temel niteliklerinden ötürü bu çalışmada cümle bilgisi kapsamında değerlendirilmesi gereken bir alt alan olarak kabul edilmiştir. Nitekim Aksan, şiirde söz sanatlarının tespit edilmesi süreçlerinde sözcük gruplarından biri olan birleşik [fiilin] anlamının göz önünde bulundurulması gerektiğini Bâkî'nin bir beytine tipik özellikleriyle yansıtılan tevriye sanatını örnek göstererek açıklar: "Güzeller mihribân olmaz demek yanlıştır ey Bâkî/ Olur vallâhi billâhi hemen yalvarı görsünler”. Aksan'a göre bu beyitte 'yalvarı görmek' (yalvarıvermek anlamında, tezlik [fiili]) birleşik [fiil] olmasının yanısıra beyitte 'yalvar' adı verilen eski bir para biriminden de söz edilmiş olmaktadır. Burada 'güzellerin sevgi göstermesi için kendilerine yalvarılması gerektiği' anlatılırken bunun 'para'yla da sağlanabileceği biçiminde ikinci bir anlam da devreye sokulmaktadır (Aksan, 1995, s. 110- 111). Aksan, bir başka çalışmasında benzer durumu yine sözcük gruplarından örnekler vererek ve bunlara bir tariz örneği ekleyerek dile getirmiştir: “Taşı düşmüş bir yüzük' [sözcük grubunun] 'süs eşyasında taş', 'Ali, taş düşürüyormuş'dan bunun örneğin 'böbrek taşı', 'bu bana taş' [sözcük grubundan da] eski deyimle 'tariz' anlamı olduğu çıkarı[labilir]" (Aksan, 1974, s. 566). Şiir; dilin alışılmış, mantığa uygun kavram birleştirmelerini zaman zaman bir yana bırakması yönü ile kendine özgü ve kimi zaman çizgi dışı bir evrene gönderim yapar. Cemal Süreya'nın 'Göçebe' şiirinde geçen 'yaşlı ve öfkeli bir otobüs' [sıfat] tamlamasında olduğu gibi (Aksan, 1974, s. 566). Buradan hareketle şiirde söz sanatlarının, özellikle de mecaza ve çok anlamlılığa dayalı sanatların tespit edilmesi süreçlerinde cümle bilgisi kapsamında değerlendirilen konu alanlarından biri olan sözcük gruplarının metne kattığı çoklu anlamların dikkate alınması gerektiği sonucuna ulaşılabilir. Buna anlambilim verilerinin sürece dâhil edilmesi gerekliliği de eklenebilir. Tüm bunlar birarada ele alındığında 2019 Türkçe Dersi Öğretim Programında yer alan söz sanatları ile ilgili kazanım ve açıklamaların cümle bilgisi kapsamında değerlendirilmesinin uygun olacağı belirtilebilir.

Aynı alt başlıkla programa yansıtılan bir diğer kazanım ve açıklamasında bu çalışmada cümle bilgisi kapsamında ele alınması gerektiği belirtilen anlatım bozuklukları üzerinde durulmuştur. Ancak burada belirtilmesi gereken bir husus vardır. Kazanıma ait açıklamada sadece dil bilgisi yönünden anlatım bozuklukları üzerinde durulmuş olmasına karşın bu çalışmada cümlede yap1 ve anlam bakımından üzerinde durulmas1 gereken bütün anlatım bozukluğu etkinlikleri çalışma kapsamına dâhil edilmiştir: "T.8.3.8. Metindeki anlatım bozukluklarını belirler. Dil bilgisi yönünden anlatım bozuklukları üzerinde durulur.” (MEB, 2019, s. 48).

Okuma/ Söz Varlığı başlığında programa taşınan bir diğer kazanım ve açıklaması, sözcük türlerinden biri olan fiilimsiler konusu etrafında şekillendirilmiştir: "T.8.3.9. Fiilimsilerin cümledeki işlevlerini kavrar. (Fiilimsilerin türleri fark ettirilir. Ekler ezberletilmez)." (MEB, 2019 , s. 48). Karahan'a göre fiilimsilere; yani bir isim-fiil, sıfat-fiil ya da zarf-fiile bağlı tamlayıc1 veya tamlayıcılardan kurulan sözcük grupları olan isim-fiil, sıfat-fiil ve zarf-fiil gruplarında ana unsur olan isim-fiil, sıfat-fiil ve zarf-fiil sonda bulunur ve fiile dayalı bütün gruplarda olduğu gibi bu gruplarda da yüklem görevi yapan isim-fiil, sıfat-fiil ve zarf-fiilin anlamı; özne, nesne, yer tamlayıcısı ve zarf adı verilen ögelerle tamamlanır: "Onu (belirtili nesne)/ biraz sonra çekeceği 
acıya (yer tamlayıcısı)/ hazırlamak (yüklem): isim-fiil grubu" örneğinde olduğu gibi. Yüklem olan isim-fiil, sıfat-fiil ve zarf-fiil; yargı bildirmez (Karahan, 2018, s. 53- 59). Bu çalışmada fiilimsilere yaslanan etkinliklerin çözümlenmesi süreçlerinde Karahan tarafindan ortaya konulan bu veriler, esas kabul edilmiştir.

Okuma/ Söz Varlığı başlığı altında programa yansıtılan "T.8.3.10. Geçiş ve bağlantı ifadelerinin metnin anlamına olan katkısını değerlendirir.(Oysaki, başka bir deyişle, özellikle, klsaca, böylece, ilk olarak ve son olarak ifadeleri üzerinde durulur)." (MEB, 2019, s. 48) kazanım ve açıklaması; cümleler arası anlam ilişkilerine yaslanan geçiş ve bağlantı ifadeleri üzerinde durulması nedeniyle bu çalışmada cümle bilgisi kapsamında ele alınması gereken bir kazanım ve açıklama olarak değerlendirilmiştir.

"T.8.3.15. Metinle ilgili sorular sorar" kazanımının da cümle bilgisi kapsamında ele alınması mümkündür. Çünkü soru cümleleri, anlamına göre cümle türlerinin alt başlıklarından biri olarak değerlendirilmektedir (MEB, 2019, s. 48).

Okuma/ Anlama başlı̆̆ı altında programa yansıtılan "T.8.3.25. Okudukları ile ilgili çıkarımlarda bulunur. Neden- sonuç, amaç- sonuç, koşul, karşılaştırma, benzetme, örneklendirme, abartma, nesnel, öznel veduygu belirten ifadeler üzerinde durulur." (MEB, 2019, s. 49) kazanım ve açıklaması ile anlam bakımından cümle türlerine gönderimde bulunulduğundan, bu çalışmada cümle bilgisi alanına dâhil edilebilecek bir kazanım ve açıklama olarak kabul edilmiştir.

Yazma başlığ 1 altında programa yansıtılan "T.8.4.7. Yazılarını zenginleştirmek için atasözleri, deyimler ve özdeyişler kullanır.", "T.8.4.15. Yazılarında uygun geçiş ve bağlantı ifadelerini kullanır. (Oysaki, başka bir deyişle, özellikle, ilk olarak ve son olarak ifadelerinin kullanılması sağlanır).”, “T.8.4.16. Yazdıklarını düzenler. a) Dil bilgisine dayalı anlatım bozuklukları bakımından yazdıklarını gözden geçirmesi ve düzeltmesi sağlanır.b) Metinde yer alan yazım ve noktalama kuralları ile sinırlı tutulur", "T.8.4.18. Cümlenin ögelerini ayırt eder.", "T.8.4.19. Cümle türlerini tanır. (Kavramsal tanımlamalara girilmez).", "T.8.4.20. Fiillerin çatı özelliklerinin anlama olan katkısını kavrar. (Kavram tanımlarına girilmeden anlamsal farklılıklara değinilir)." (MEB, 2019, s. 50) kazanım ve açıklamaları; cümle kuruluşundaki atasözü, deyim ve özdeyişler üzerinde durulması, cümleler arası geçiş ve bağlantı ifadelerinin konu edilmesi, anlatım bozuklukları, cümle ögeleri, cümle türleri ve fiillerde çatı konularını yansılaması bakımından bu çalışmada cümle bilgisi kapsamında değerlendirilmiş ve gerçekleştirilen etkinlik çözümlemesi süreçlerinde bu kazanım ve açıklamalarına gönderimde bulunulmuştur.

\section{Araştırmanın Amacı}

Çalışmanın amacı, 8. Sınıf Türkçe Ders Kitabı ’ndaki (MEB, 2019) sekiz temada yer alan okuma ve dinleme/ izleme metinlerinin işleniş süreçlerine yönelik oluşturulmuş cümle bilgisi etkinliklerinin tespit edilmesi ve eleştirel bir bakışla yorumlanıp değerlendirilmesidir. Çalışmada benzer işlem, "Tema Sonu Değerlendirme Çalışmaları" bölümlerinde yer alan soru maddeleri için de gerçekleştirilmiştir.

\section{Araştırmanın Yöntemi}

Araştırmada nitel araştırma yöntemlerinden betimsel yöntem kullanılmıştır. "Betimsel çalışmalar, verilen bir durumu aydınlatmak, standartlar doğrultusunda değerlendirmeler yapmak ve olaylar arasında olası ilişkileri ortaya çıkarmak için yürütülür" (Çepni, 2009). Çalışma, betimsel (descriptive) araştırma türlerinden biri olan tarama modelinde (Büyüköztürk, 2010, s. 21) gerçekleştirilmiş̧ir. "Tarama modelleri, geçmişte ya da hâlen var olan bir durumu var olduğu şekliyle betimlemeyi amaçlayan araştırma yaklaşımlarıdır. Araştırmaya konu olan olay, birey ya da nesne; kendi koşulları içinde ve olduğu gibi tanımlanmaya çalış1ır. Onları, herhangi bir şekilde değiştirme, etkileme çabası gösterilmez. Bilinmek istenen şey vardır ve oradadır. Önemli olan, onu uygun bir biçimde gözleyip belirleyebilmektir” (Karasar, 1994, s. 77). 


\section{Araştırmanın İncelenen Dokümanları}

Araştırmada 8. Sınıf Türkçe Ders Kitabı (MEB, 2019), doküman kabul edilmiş ve bu kitaptaki cümle bilgisi etkinlikleri incelenmiştir.

\section{Verilerin Toplanması ve Analizi}

Verilerin toplanması sürecinde doküman kabul edilen kitapta yer alan cümle bilgisine yönelik oluşturulmuş bütün etkinlikler tespit edilerek fişlenmiş, elde edilen verilerin analizi sürecinde ise tespit edilen bu etkinlikler, 2019 Türkçe Dersi Öğretim Programı'ndaki kazanımlar ile cümle bilgisi alanyazınının sunduğu veriler ışığında yorumlanmış ve bunların hangi gerekçe ile cümle bilgisi kapsamında değerlendirilebileceği ortaya konmaya çalışılımıştır. Bu süreçte yer yer bu etkinliklerin alanyazındaki güncel veriler ışığında nasıl güncellenebileceği konusuna da değinilmiş, çalışmanın sonuç bölümünde bu yönde yapılan tekliflere yapılandırmacı yaklaşım ile dil bilgisi öğretimi konusunda görüş ortaya koyan araştırmacıların verileri ışığında eklemeler yapılmıştır.

Örneğin; 7. temanın 2. metni olan Rüzgâr'ın 8. etkinliğinde (Eselioğlu, Set ve Yücel; 2019, s. 233) öğrencilere 10 cümle verilmiş ve onlardan bu cümleleri yükleminin türüne ve yerine; anlamına ve yapısına göre sınıflandırmaları istenmiştir. Buradan hareketle bu etkinliğin 2019 Türkçe Dersi Öğretim Programı'nın “T.8.4.19. Cümle türlerini tanır. (Kavramsal tanımlamalara girilmez)." kazanım ve açıklamasına uygun biçimde düzenlenmiş olduğu sonucuna ulaşılabilir:

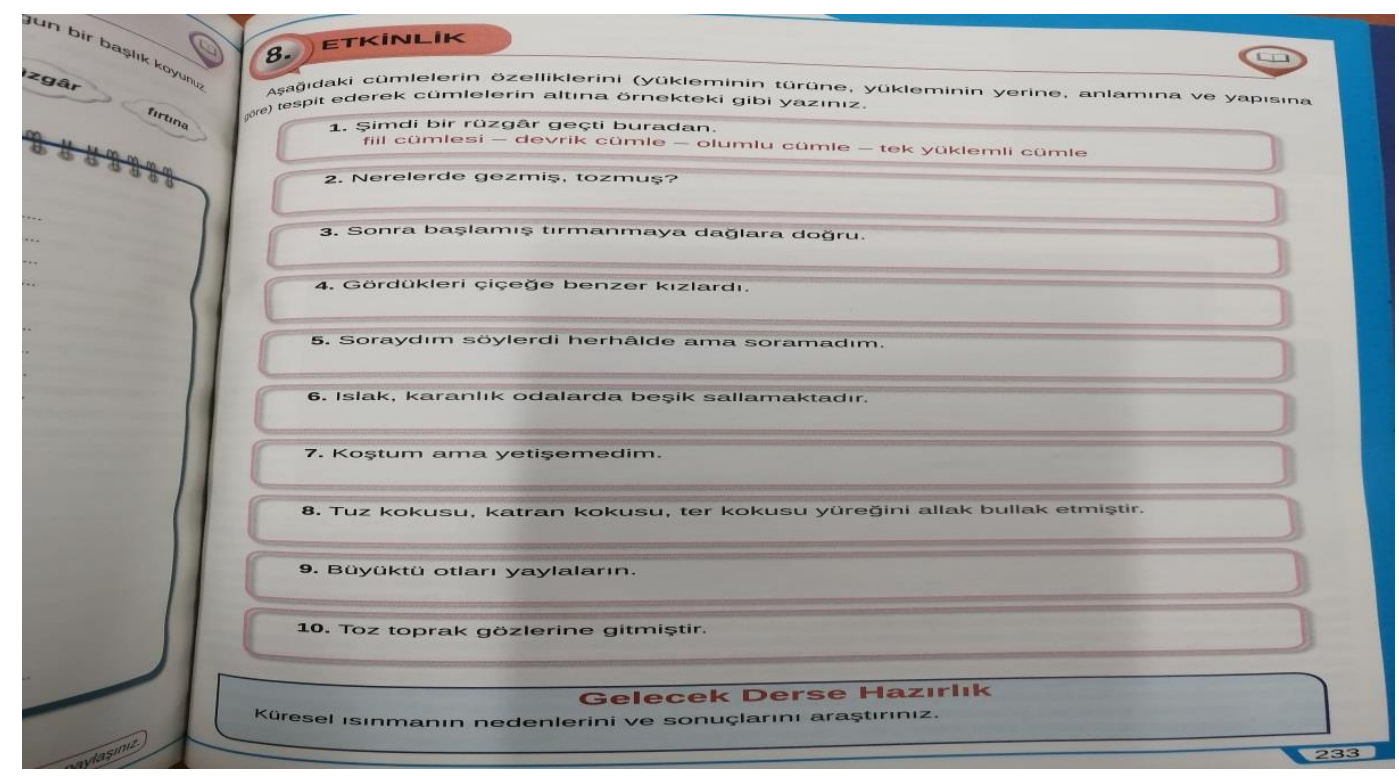

En son çıkan ve 28.05.2019 tarihinde yayımlanan 8. Sinıf Türkçe Ders Kitabı 'ndaki (MEB, 2019) cümle bilgisi etkinliklerinin ele alındığı bu çalışma, bu açıdan alanyazında önemlidir.

\section{Bulgular ve Yorum}

Aşağıda 8. Sinıf Türkçe Ders Kitabı'ndaki (MEB, 2019) sekiz temada yer alan okuma ve dinleme/ izleme metinlerinin işleniş süreçlerine yönelik oluşturulmuş cümle bilgisi etkinliklerinin tespit edilmesi ve eleştirel bir bakışla yorumlanıp değerlendirilmesine ilişkin elde edilen bulgulara yer verilmiştir.

\section{Tema: Erdemler}

Temada "İyimserlik ve Kötümserlik Üzerine" (Yusuf Çotuksöken, Deneme), "Kaşağı" (Ömer Seyfettin, Hikâye), "İnsanla Güzel”" (İlhan Geçer, Şiir) başlıklarını taşıyan üç okuma; "Kedi ile Fare" (Beydeba, Fabl) başlığını taşıyan bir dinleme/ izleme, "Ayaz'ın Definesi" (Mevlânâ, 
Tahkiyeye Dayalı Metin) başlığını taşıyan bir serbest okuma metni olmak üzere toplam beş metin bulunmaktadır.

Tablo 1: 1. Temada Yer Alan Etkinliklerin Cümle Bilgisi Konularına Dağılımı

\section{Tema: Erdemler}

\begin{tabular}{|c|c|c|c|c|}
\hline $\begin{array}{l}\text { Metinler } \\
\text { Cümle Bilgisi Konular1 }\end{array}$ & $\begin{array}{c}\text { İyimserlik ve } \\
\text { Kötümserlik Üzerine }\end{array}$ & Kaşağı & İnsanla Güzel & Kedi ile Fare \\
\hline $\begin{array}{l}\text { Deyimlerin cümlede } \\
\text { kullanılması }\end{array}$ & 2. Etkinlik & & & \\
\hline $\begin{array}{l}\text { Kanıtlanabilirlik } \\
\text { açısından cümle türleri }\end{array}$ & 6. Etkinlik & & & \\
\hline $\begin{array}{l}\text { Çekimli fiil- fiilimsi } \\
\text { fark1 }\end{array}$ & 8.a. Etkinlik & & & \\
\hline Fiilimsiler & 8.b. Etkinlik & & & \\
\hline $\begin{array}{l}\text { Cümle yapılanışındaki } \\
\text { atasözleri }\end{array}$ & & 2.Etkinlik & 8. Etkinlik & 2. Etkinlik \\
\hline $\begin{array}{l}\text { Cümle yapılanışındaki } \\
\text { özdeyişler }\end{array}$ & & & 8. Etkinlik & \\
\hline $\begin{array}{l}\text { Anlamına göre cümle } \\
\text { türleri }\end{array}$ & & 5. Etkinlik & & \\
\hline $\begin{array}{l}\text { İsim-fiiller ve isim-fiil } \\
\text { ekleri }\end{array}$ & & 6. Etkinlik & & \\
\hline Cümlede anlam & & & 4 ve 5. Etkinlik & \\
\hline $\begin{array}{l}\text { Sifat-fiiller ve sıfat-fiil } \\
\text { ekleri }\end{array}$ & & & 6. Etkinlik & \\
\hline Sözcük grupları & & & & 1. Etkinlik \\
\hline $\begin{array}{l}\text { Sözcüklerin/ sözcük } \\
\text { gruplarının cümlede } \\
\text { kullanılması }\end{array}$ & & & & 1. Etkinlik \\
\hline
\end{tabular}

Tablo 1'de 1. temada yer alan metinlere yönelik olușturulmuş etkinliklerin hangi cümle bilgisi konusu etrafında şekillendirildiği gösterilmektedir. Bu dağılım üzerine yapılan yorum ve değerlendirmeler ise aşağıda sıralanmaktadır:

“İyimserlik ve Kötümserlik Üzerine” metninin 2. etkinliğinde öğrencilere üç deyim verilmiş, onlardan bu deyimlerin önce anlamını bulmaları ardından da bunları birer cümlede kullanmaları istenmiştir: göze almak, batağa saplanmak, göz ardı etmek. Etkinlik hem bu deyimlerin birer sözcük grubu (isim- fiil grubu) yapılanışında olmaları hem de cümlede kullanılmalarının istenilmesi yönü ile cümle bilgisi kapsamında ele alınmaya uygundur.

6. etkinlikte öğrencilere sekiz cümle verilmiș ve onlardan bu cümlelerden öznel olanların bașına "Ö", nesnel olanların bașına ise "N" yazmaları istenmiștir: "Sadece kötümserlerden oluşan bir toplum çekilir olmaz" (Ö), "Yazarın son kitabı iki yüz sayfadan oluşuyor" (N). Kanttlanabilirlik açısından cümle türleri ve dolayısıyla cümlede anlam konusu üzerinde durulan bu etkinliğin cümle bilgisi kapsamında değerlendirilmesi uygundur.

8. etkinliğin a basamağında öğrencilere dört cümle verilmiş ve onlardan bu cümlelerde koyu yazılan sözcüklerin isim ya da fiil olduğuna karar vermeleri istenmiştir: "Kuzey, babasıyla derede balı tutuyordu" (fiil), "Balık tutmak Kuzey'i çok mutlu ediyordu” (isim). Çekimli fiiller ile fiilimsiler arasındaki farklılıkların farkında olma süreçlerine yaslanan bu etkinliğin bu açıdan cümle bilgisi kapsamında ele alınması mümkündür.

Etkinliğin $\mathrm{b}$ basamağında öğrencilere sekiz cümle verilmiş ve onlardan bu cümlelerde fiil kökünden türediği hâlde fiil özelliği taşımayan sözcüklerin (fiilimsilerin) altını çizmeleri istenmiştir: "Insanlar, genelde 'iyimserler' ve 'kötümserler' olarak ikiye ayrılır" (zarf- fiil). 
Cümlede fiilimsilerin tespit edilmesine yaslanan bu etkinliği bu açıdan cümle bilgisi kapsamında değerlendirmek mümkündür.

"Kaşağı" metninin 2. etkinliğinde yer alan 7. soruda öğrencilerden metnin ana fikrine uygun bir atasözü yazmaları istenmiştir. Atasözleri, yapılanış itibariyle cümle kuruluşunda olduğundan bu etkinliğin cümle bilgisi kapsamında ele alınması uygundur.

5. etkinlikte öğrencilere altı cümle verilmiş ve onlardan bu cümlelerdeki anlam ilişkilerine göre boșluklara uygun harfleri yerleștirmeleri istenmiștir: A, amaç- sonuç cümlesi; $\mathbf{B}$, neden- sonuç cümlesi; C, koşul- sonuç cümlesi. "Annem İstanbul'a gittiği iç̧in Dadaruh'un yanından hiç ayrllmıyorduk" (B: neden- sonuç cümlesi), "Kaşağıyı aramak için penceresiz, küçük bir odaya girdim" (A: amaç- sonuç cümlesi), "Doğruyu söylersen bir insan iftiradan kurtulacak" (C: koşulsonuç cümlesi). Cümlede anlam konusuna odaklanılan etkinlik, bu açıdan cümle bilgisi kapsamında ele alınmaya uygundur.

6. etkinlikte öğrencilere yedi cümle verilmiş ve onlardan bu cümlelerdeki isim- fiilleri bularak isim- fiil eklerini de örnekteki gibi göstermeleri istenmiștir: "Öfkemi sanki kașağıdan çıarmak istedim”, -mak. Bir sözcük grubu olarak fiilimsilere ve fiilimsi eklerine odaklanılan etkinlik, bu açıdan cümle bilgisi kapsamında ele alınmaya uygundur.

“İnsanla Güzel” metninin 4 ve 5. etkinliğinde öğrencilere şiirden alıntılanan dizeler verilmiș ve onlardan bu dizelerdeki söz sanatlarını karșılarına yazmaları istenmiștir: benzetme, abartma, kişileştirme, konuşturma, karşıtlık. "Güleriz ağlanacak hâlimize...", karşıtlık. Dizelerdeki söz sanatlarının tespit edilmesi süreçlerinde öğrenciler, cümlede anlam konusuna ait zihinsel şemalarını işleteceklerinden bu etkinliğin cümle bilgisi kapsamında değerlendirilmesi uygundur.

6. etkinlikte öğrencilere bir metin verilmiş ve onlardan bu metinde geçen sifat- fiilleri (ortaçları) ve eklerini tespit ederek örnekteki gibi göstermeleri istenmiştir: "Zülal'in baktı̆̆g resimler unutulmaz güzel günlerden hatıraydı”, -tığı, -maz. Bir sözcük grubu olarak fiilimsiler ve fiilimsi ekleri üzerinde durulan etkinliğin bu açıdan cümle bilgisi kapsamında ele alınması uygundur.

8. etkinlikte öğrencilere bir dörtlük verilmiş, onlardan bu dörtlükten hareketle bilgilendirici bir metin yazmaları ve bu süreçte olușturdukları metni atasözü ve özdeyișlerle zenginleștirmeleri istenmiştir. Etkinlik, hem metin oluşturma süreçlerinde cümleler oluşturulması ve cümleler arası anlam ilişkileri kurulması hem de oluşturulacak metnin birer cümle yapılanışında olan atasözü ve özdeyişlerle zenginleştirilmesi süreçlerine yaslanan yönü ile cümle bilgisi kapsamında değerlendirilmeye uygundur.

"Kedi ile Fare" dinleme/ izleme metninin 1. etkinliğinde öğrencilere anlamı ve harflerinden birkaçı belirtilen on bir sözcük/ sözcük grubu verilmiş ve onlardan öncelikle bu sözcük/ sözcük gruplarını bulmaları ardından da onları anlamlarına uygun biçimde birer cümlede kullanmaları istenmiştir: "Hezimet: Yenilgi", "Rehin Almak: Bir anlaşma, sözleșme veya isteğin yerine getirilmesini sağlamak için bir kimseyi alıkoymak". Etkinlik, verilen ifadelerden bazılarının sözcük grubu yapılanışında olması (rehin almak ve telkin etmek, isim- fiil grubu) ve tamamının birer cümlede kullanılması süreçlerine yaslanan yönü ile cümle bilgisi kapsamında incelenmeye uygundur.

2. etkinliğin ikinci sorusunda öğrencilerden metindeki farenin sergilemiş olduğu tavra örnek bir atasözü söylemeleri istenmiştir. Atasözleri, cümle yapılanışında olduğundan etkinliğin cümle bilgisi kapsamında ele alınması uygundur.

“Tema Sonu Değerlendirme Çalışmaları” bölümünün 5. sorusunda öğrencilere farklı şiirlerden alıntılanmış dizeler verilmiş ve onlardan bu dizelerde kullanılan söz sanatlarını yazmaları 
istenmiştir: "Her şey yerli yerinde; bir dolap uzaklarda/ Azapta bir ruh gibi glcırdlyor durmadan" benzetme sanatı. Söz sanatlarının dizeleri kuran cümlelere kattığı anlamın çözümlenerek tespit edilmesi süreçleri ile şekillendirilen etkinliğin bu açıdan cümle bilgisi kapsamında incelenmesi uygundur.

6. soruda öğrencilere bir cümle verilmiş ve onlardan bu cümlede yer alan "uçmak" sözcügünün seçeneklerde verilen cümlelerden hangisinde bu cümle ile aynı anlamda kullanılmış olduğu sorulmuştur: "Uçuç böceği, biraz havalanıp bir başka çiçeğe kadar uçtu” // "D) Bacadaki baykuş, sesimi duyunca uçtu”. Cümlede yüklemin anlamı konusunun işlendiği bu maddenin cümle bilgisi kapsamında değerlendirilmesi uygundur.

7. soruda öğrencilere seçeneklerde verilen cümlelerden hangisinin kanttlanabilirlik açısından diğerlerinden farklı olduğu sorulmuştur: “C) Kurtuluş Savaşı 'na bir kasabadan bakttğ 'Küçük Ăga'da anlatım sürükleyicidir”. Cümlede anlam konusunun öznel ve nesnel yargılı cümleler konusuna odaklanılan etkinliğin bu açıdan cümle bilgisi kapsamında ele alınması uygundur.

8. soruda öğrencilere seçeneklerde verilen cümlelerin hangisinde isim-fiil kullanıldığ 1 sorulmuştur: "Duvara çivi çakmak yasaktır bizim evde". Sözcük türlerinden fiilimsiler konusunun ele alındığı etkinliğin cümle bilgisi kapsamında değerlendirilmesi mümkündür.

9. soruda öğrencilere seçeneklerde verilen dizelerin hangisinde fiilimsiye yer verildiği sorulmuştur: "A) Vicdânım o gece dünyayı haviydi/ Gördüğüm şeylerin cümlesi maviydi”. "Gördüğüm” sözcüğü, sıfat- fiil eki almıştır. Fiilimsiler konusuna odaklanılan etkinliğin, bu açıdan bakıldığında cümle bilgisi kapsamında incelenmesi uygundur.

\section{Tema: Millî Mücadele ve Atatürk}

Temada "Bayrağımızın Altında" (Halide Edip Adıvar, Hikâye), "Atatürk ve Müzik"(Seda Bayındır Uluskan, Makale), "Kınalı Ali’nin Mektubu" (Çukurova Üniversitesi Türkoloji Araştırmaları Merkezi, mektubun aslı Çanakkale Müzesindedir) başlı̆̆ını taşıyan üç okuma;“Atatürk’ü Gördüm” (Muzaffer İzgü, Anı- Öykü) başlı̆̆ını taşıyan bir dinleme/ izleme ile "Bir Bayrak Rüzgâr Bekliyor" (Arif Nihat Asya, Şiir) başlığını taşıyan bir serbest okuma metni olmak üzere toplam beş metin bulunmaktadır. 
Tablo 2: 2. Temada Yer Alan Etkinliklerin Cümle Bilgisi Konularına Dağılımı

\begin{tabular}{|c|c|c|c|c|}
\hline & & ma: Millî Mücadele & tatürk & \\
\hline $\begin{array}{l}\text { Metinler } \\
\text { Cümle Bilgisi } \\
\text { Konular1 } \\
\end{array}$ & $\begin{array}{c}\text { Bayrağımızın } \\
\text { Altında }\end{array}$ & Atatürk ve Müzik & $\begin{array}{c}\text { Kınalı Ali'nin } \\
\text { Mektubu }\end{array}$ & $\begin{array}{l}\text { Atatürk'ü } \\
\text { Gördüm }\end{array}$ \\
\hline $\begin{array}{l}\text { Cümlede düşünceyi } \\
\text { geliştirme yolları }\end{array}$ & 4. Etkinlik & & & \\
\hline $\begin{array}{l}\text { Zarf-fiiller ve zarf- } \\
\text { fiil ekleri }\end{array}$ & 5. Etkinlik & & & \\
\hline $\begin{array}{l}\text { Sözcük grupları ve } \\
\text { anlamları }\end{array}$ & & 1. Etkinlik & & \\
\hline $\begin{array}{l}\text { Cümle } \\
\text { kuruluşundaki } \\
\text { özdeyişler }\end{array}$ & & 4. Etkinlik & & \\
\hline Fiilimsi türleri & & 6. Etkinlik & 6. Etkinlik & \\
\hline $\begin{array}{l}\text { Sözcük grubu } \\
\text { yapılanışındaki } \\
\text { deyimler }\end{array}$ & & & 2. $\quad$ Etkinlik & \\
\hline $\begin{array}{l}\text { Deyimlerin } \\
\text { cümlede } \\
\text { kullanılmas1 }\end{array}$ & & & 2. $\quad$ Etkinlik & \\
\hline $\begin{array}{l}\text { Anlamına göre } \\
\text { cümle türleri }\end{array}$ & & & 3. Etkinlik & \\
\hline $\begin{array}{l}\text { Cümleler arası } \\
\text { geçiş ve bağlantı } \\
\text { ifadeleri }\end{array}$ & & & 5. Etkinlik & 7.b. Etkinlik \\
\hline
\end{tabular}

Tablo 2'de 2. temada yer alan metinlere yönelik oluşturulmuş etkinliklerin hangi cümle bilgisi konusu etrafinda şekillendirildiği gösterilmektedir. Bu dağılım üzerine yapılan yorum ve değerlendirmeleri şöyle sıralamak mümkündür:

"Bayrağımızın Altında" metninin 4. etkinliğinde öğrencilerden metinden "örneklendirme, benzetme ve karşlaş̧ırma" cümleleri bularak örnekteki gibi yazmaları istenmiştir: "Birdenbire buruşuk yüzü üzerinden bir gözyaşı seli aktı" Abartma; "Zafer yolunda unutamayacağım yüzlerden biri, Hatice Nine'nin yüzüdür" Örneklendirme; "Boş sokaklarda kadın erkek dolaşlyor, hep çocuklar gibi koşuşuyorlardı" Benzetme; "Oysaki en fakiri, en ihtiyarı ve en hâlsiziydi" Karşılaştırma. Cümlede düşünceyi geliştirme yolları üzerinde durulan etkinliğin, bu açıdan cümle bilgisi kapsamında ele alınması uygundur.

5. etkinlikte öğrencilere sekiz cümle verilmiş ve onlardan bu cümlelerde geçen zarf-fiilleri (bağ-fiil) bularak zarf-fiil ekini örnekteki gibi karşılarına yazmaları istenmiştir: "Ortalık ağarıyor, hâlâ kadınlar gelip gidiyor" -ip, "Giderken döndü ve sikı sıkı bir daha boynuma sarıldı" -ken. Sözcük türlerinden fiilimsiler ve ekleri konusunun ele alındığı etkinliğin bu açıdan cümle bilgisi kapsamında değerlendirilmesi uygundur.

“Atatürk ve Müzik" metninin 1. etkinliğinde öğrencilere on iki sözcük/ sözcük grubu bazı harfleri boş bırakılmış biçimde ve anlamları ile birlikte verilmiştir. Onlardan anlamları verilen bu sözcük/ sözcük gruplarını tahmin ederek bulmaları istenmiştir. Verilen ifadelerden bazıları sözcük grubu (isim- fiil grubu) yapılanışında olduğu için bu etkinliğin, cümle bilgisi kapsamında ele alınması uygundur: damga vurmak, iştirak etmek, nabız yoklamak, icra etmek.

4. etkinlikte öğrencilere Atatürk'e ait altı özdeyiş verilmiş ve onlardan bu özdeyişlerin konusunu örnekteki gibi yazmaları istenmiştir: "Ben icap ettiği zaman en büyük hediyem olmak üzere Türk milletine canımı vereceğim”, Millet Sevgisi. Etkinlik, hem verilen özdeyişlerin cümle 
kuruluşunda oluşları hem de konularının sözcük grubu (belirtisiz isim tamlaması) biçiminde ifade edilebilmesi açısından cümle bilgisi kapsamında değerlendirilmeye uygundur.

6. etkinlikte öğrencilere altı cümle verilmiş ve onlardan bu cümlelerde geçen fiilimsileri bulup türlerini belirleyerek etkinlikte kendilerine verilen tabloda uygun bölüme işaretlemeleri istenmiştir: "Alafranga müziğe yönelip halkı buna teşvik etmiştir" (zarf- fiil), "Manastır' en sevdiği türküler arasındadır" (sıfat- fiil), "İlk adım, konservatuvarların kurulması olmuştur" (isim- fiil). Fiilimsilere ve fiilimsi türlerinin birbirinden ayırt edilmesi süreçlerine odaklanılan etkinlik, bu açıdan ele alındığında cümle bilgisi kapsamında değerlendirilmeye uygundur.

"Kınalı Ali'nin Mektubu" metninin 2. etkinliğinde öğrencilere beş deyim ile bu deyimlerin anlamları verilmiş ve onlardan öncelikle bu deyimleri anlamları ile eşleştirmeleri, ardından da cümlede kullanmaları istenmiştir: kına yakmak, geri dönmek, dalga geçmek, selam etmek, büyüklerin ellerinden küçüklerin gözlerinden öpmek. Etkinlik, hem verilen deyimlerin birer sözcük grubu (isim- fiil grubu) yapılanışında olması hem de cümlede kullanılmalarının istenmesi yönü ile cümle bilgisi kapsamında ele alınmaya uygundur.

3. etkinlikte öğrencilerden işlenen metne yönelik üç soru cümlesi oluşturmaları ve ardından bu soruları arkadaşlarına yöneltmeleri istenmiştir. Soru cümleleri, anlamına göre cümle türlerinden biri olduğundan etkinlikte gerçekleştirilen bu sürecin cümle bilgisi kapsamında ele alınması mümkündür.

5. etkinlikte öğrencilere bir metin verilmiş ve onlardan bu metinde geçen geçiş ve bağlantı ifadelerinin altını çizip bu ifadelerin anlatıma olan katkısını yazmaları istenmiştir: şüphesiz ki, ilk olarak, özellikle, kisaca, son olarak/ Bu ifadeler bir düşünceden diğerine geçiş sağlayan ve düşünceyi destekleyen, açılayan ifadelerdir. Cümleler arası anlam ilişkileri konusuna yaslanan geçiş ve bağlantı ifadelerinin ele alındığı etkinlik, bu açıdan cümle bilgisi kapsamında incelenmeye uygundur.

6. etkinlikte öğrencilere Mustafa Kemal Atatürk'ün Pierre Loti’ye 12 Temmuz 1921 tarihinde yazmış olduğu bir mektup verilmiş ve onlardan bu mektupta geçen fiilimsileri bulup türlerini belirleyerek etkinlikte kendilerine verilen isim- fiil, sıfat- fiil ve zarf- fiil kutucuklarından uygun olanına yazmaları istenmiştir: inanmanızı, iyileşmeniz, gülümsemeye, yenilemekten, isimfiil; aldı̆̆ım, duygulanmış, beslediğim, sifat- fiil; olarak, öğrenince, yararlanarak, zarf- fiil. Fiilimsiler konusu üzerinde durulan etkinliğin bu açıdan cümle bilgisi kapsamında değerlendirilmesi uygundur.

“Atatürk'ü Gördüm” dinleme/ izleme metninin 2. etkinliğinde öğrencilere yöneltilen beşinci soruda "Atamızın aydınlı̆̆l; gözlerimize, yüzlerimize bulaşmış̧" cümlesinde ne anlatılmak istendiği sorulmuştur. Cümlede anlam konusuna yaslanan bu etkinliğin bu açıdan cümle bilgisi kapsamında incelenmesi mümkündür.

7. etkinliğin a basamağında öğrencilere A. Rıza Ergüven'in "Atatürk'ü Gördüm Düşümde" şiiri verilerek metni okumaları, b basamağında ise bu şiirin konusu ve ana duygusuyla ilgili düşüncelerini anlatan bir konuşma metni hazırlamaları, bu konuşma metninde de uygun geçiş ve bağlantı ifadelerini kullanmaları istenmiştir: oysaki, özellikle, başka bir deyişle, kısaca, böylece, ilk olarak, son olarak $v b$. Beceriler arası geçişkenliğe yaslanarak konuşma becerisinin sürece dâhil edildiği etkinlikte cümleler arası anlam ilişkilerinin ölçüt kabul edilerek kullanımını gerekli kılan geçiş ve bağlantı ifadeleri konusu üzerinde durulması, bu etkinliğin cümle bilgisi kapsamında ele alınmasını gerekli kılmaktadır.

“Tema Sonu Değerlendirme Çalışmaları" bölümünde öğrencilere Ceyhun Atuf Kansu'nun "Cumhuriyet Ağacı" metni verilmiş, 2. sorusunda onlara yazarın bu metinde cumhuriyeti neye benzettiği sorulmuştur: Yazar, cumhuriyeti çınar ă̆acına benzetmiştir. Söz sanatlarından 
benzetmenin kullanıldığ cümlenin tespit edilmesine yaslanan madde, cümlede anlam konusu etrafında şekillendirilmesi nedeniyle cümle bilgisi kapsamında değerlendirilebilir.

5. soruda öğrencilerden "Yerli halıları gördüm, koyu sıcak kırmızılarla diri maviler ağır basıyordu" cümlesinde geçen "ağır basmak" sözcük grubunun cümleye kattığı anlamı yazmaları istenmiștir: taşılı̆̆g özellikler üstün gelmek. Soru maddesi, hem anlamı sorgulanan ifadenin bir sözcük grubu (isim- fiil grubu, deyim) yapılanışında olması hem de bu ifadenin cümleye katmış olduğu anlamın sorgulanması yönüyle cümle bilgisi kapsamında ele alınmaya uygundur.

Doğru- yanlış maddesi biçiminde hazırlanan 7. soruda öğrencilere cümle bilgisi hakkında beş bilgi sunulmuş ve onlardan bu bilgilerden doğru olanların başına " $D$ ", yanlış olanlarınkine ise "Y" yazmaları istenmiştir: "İzlediğimiz film çok etkileyiciydi" cümlesinde isim- fiil vardır (Y, sıfatfiil vardır), "Fındık toplamak gerçekten çok zormuş" cümlesinde birden fazla fiilimsi vardır (Y, sadece bir fiilimsi vardır: toplamak), "Istediği oyuncak alınınca dünyalar onun oldu" cümlesinde "alınınca" sözcüğü zarf- fiildir (D), "Sokaktan gelen gürültülerle uyandık geçen sabah" cümlesinde "geçen" sözcügü isim- fiildir (Y, sıfat- fiildir), "İstanbul'dan getirdiği hediyeler çok ilginç" cümlesinde "getirdiği”" sözcügü sıfat- fiildir (D). Fiilimsiler konusunun ele alındığı soru maddesinin cümle bilgisi kapsamında değerlendirilmesi uygundur.

8. soruda seçeneklerin hangisinde neden- sonuç cümlesi kullanıldığı sorulmuştur: "Deniz dalgalı olduğu için rahatça yüzemedik". Cümlede anlam konusu etrafinda şekillendirilen çoktan seçmeli soru maddesi, bu açıdan cümle bilgisi kapsamında ele alınmaya uygundur.

9. soru maddesinde öğrencilere "Uzaktadır her şey: gökyüzü, deniz.../ Her an peşimizden koşan gölgemiz" dizelerindeki fiilimsinin türce özdeşinin seçeneklerde verilen dizelerden hangisinde verilmiş olduğu sorulmuştur: “A) Kardır yağan üstümüze geceden/ Yağmurlu, karanlık düşünceden"sıfat- fiil. Edebî metin merkezli şekillendirilen soru maddesinde dizelerde kullanılan fiilimsinin türünün belirlenmesi ve bu fiilimsinin özdeşinin seçeneklerde sunulan dizelerden hangilerinde kullanıldığının tespit edilmesi süreçlerinin işletilmiş olması, maddenin cümle bilgisi kapsamında değerlendirilmesini gerekli kılmaktadır.

\section{Tema: Bilim ve Teknoloji}

Temada "Gündelik Hayatımızda E- Hastalıklar" (Ali Murat Kırık), "Simit ve Peynir'le Bilim İnsanı Öyküleri” (Bilgin Ersözlü, Çizgi Roman), "Parktaki Bilim” (Yasemin Şahin) başlığını taşıyan üç okuma; "Uzay Giysileri" başlığını taşıyan bir dinleme/ izleme ile "Eski Çağlardan Beri Dişlerimize Çok İyi Baktık" (Bilge Nur Karagöz) başlığını taşıyan bir serbest okuma metni olmak üzere toplam beş metin yer almaktadır. 
Tablo 3: 3. Temada Yer Alan Etkinliklerin Cümle Bilgisi Konularına Dağılımı

\begin{tabular}{|c|c|c|c|c|}
\hline \multicolumn{5}{|c|}{$\begin{array}{l}\text { 3. Tema: Bilim ve Teknoloji } \\
\end{array}$} \\
\hline $\begin{array}{l}\text { Metinler } \\
\text { Cümle Bilgisi } \\
\text { Konuları }\end{array}$ & $\begin{array}{c}\text { Gündelik } \\
\text { Hayatımızda E- } \\
\text { Hastalıklar }\end{array}$ & $\begin{array}{c}\text { Simit ve } \\
\text { Peynir'le } \\
\text { Bilim } \\
\text { İnsanı } \\
\text { Öyküleri } \\
\end{array}$ & Parktaki Bilim & Uzay Giysileri \\
\hline Sözcük grupları & 4. $\quad$ Etkinlik & & & \\
\hline Cümlenin ögeleri & 10. Etkinlik & 8. Etkinlik & 8. Etkinlik & 7. Etkinlik \\
\hline $\begin{array}{l}\text { Cümleler arası geçiş } \\
\text { ve bağlantı ifadeleri }\end{array}$ & & 6. Etkinlik & & \\
\hline $\begin{array}{l}\text { Anlamına göre cümle } \\
\text { türleri }\end{array}$ & & & $\begin{array}{l}\text { 2. Etkinlik } \\
\text { 7.b. Etkinlik }\end{array}$ & \\
\hline $\begin{array}{l}\text { Yükleminin yerine } \\
\text { göre cümle türleri }\end{array}$ & & & 7.b. Etkinlik & \\
\hline Cümlede anlam & & & 4. Etkinlik & \\
\hline $\begin{array}{l}\text { Cümle ya da sözcük } \\
\text { grubu yapılanışındaki } \\
\text { atasözü, deyim ve } \\
\text { özdeyişler }\end{array}$ & & & 7.b. Etkinlik & \\
\hline $\begin{array}{l}\text { Sözcüklerin cümlede } \\
\text { kullanılmas1 }\end{array}$ & & & & 1. Etkinlik \\
\hline
\end{tabular}

Tablo 3'te 3. temada yer alan metinlere yönelik oluşturulmuş etkinliklerin hangi cümle bilgisi konusu etrafında şekillendirildiği gösterilmektedir. Bu dağılım üzerine yapılan yorum ve değerlendirmelerin şöyle sıralanması mümkündür:

"Gündelik Hayatımızda E- Hastalıklar" metninin 4. etkinliğinde öğrencilerden metinde koyu ve farklı yazı karakteri ile yazılmış sözcük ve sözcük gruplarını tespit etmeleri ve yazı karakterinin bu şekilde kullanılmasının gerekçesini belirtmeleri istenmiştir: E-hastalıklar, Dijital bağımlılık, phubbing, siberkondria, Elektronik uykusuzluk, fantom, vibrasyon. Yazı karakterini bu şekilde kullanmanın amacı, okuyucunun dikkatini çekmektir. Farklı yazı karakteri ile öğrencilere sunulan ifadelerin bir kısmının sözcük grubu yapılanışında olması nedeni ile bu etkinliğin cümle bilgisi kapsamında değerlendirilmesi mümkündür: E-hastalıklar (sıfat tamlaması), Dijital bağımlılık (sıfat tamlaması), Elektronik uykusuzluk (sıfat tamlaması).

10. etkinlikte öğrencilere beş cümle verilmiş ve onlardan bu cümlelerdeki özne ve yüklemlerin altını çizmeleri istenmiştir: "Akıllı telefonlarını sürekli elinde tutan kullanıcılar, karşısındaki kişiyi önemsememektedirler”. Cümlenin ögelerinden özne ve yüklem konusunun ele alındığı etkinlik, bu açıdan cümle bilgisi kapsamında değerlendirilmeye uygundur.

“Simit ve Peynir’le Bilim İnsanı Öyküleri” metninin 6. etkinliğinde öğrencilere "İnsanlığa yararlı bir icat yapmanız gerekirse neyi icat etmek isterdiniz?" sorusu yöneltilerek onlardan bu konuda arkadaşlarına bir konuşma hazırlamaları ve bu süreçte "oysaki, özellikle, kısaca, son olarak" gibi geçiş ve bağlantı ifadelerinden uygun olanları kullanmaya özen göstermeleri istenmiştir. Bu geçiş ve bağlantı ifadelerinin cümleler arası anlam ilişkilerine bağlı olarak kullanılma süreçleri, etkinliğin cümle bilgisi kapsamında ele alınmasını gerekli kılmaktadır.

8. etkinlikte öğrencilere bazı özne ve yüklemlerin yanlış gösterildiği altı cümle verilmiş ve onlardan bu cümlelerdeki yanlışları düzelterek altlarına doğru olan özne ve yüklemleri yazmaları istenmiştir: "Biz, Türkiye'de Mardin ilinin Savur ilçesindeyiz" cümlesinde yüklem, "Mardin ilinin Savur ilçesindeyiz" olmalıdır. Cümlenin ögelerinden özne ve yüklem üzerinde durulan bu etkinliğin bu açıdan cümle bilgisi kapsamında ele alınması uygundur. 
"Parktaki Bilim" metninin 2. etkinliğinde öğrencilerden metinle ilgili dört soru oluşturarak bu soruları arkadaşlarına yöneltmeleri istenmiştir. Soru cümleleri, anlamına göre cümle türlerinden biri olduğundan bu etkinliğin cümle bilgisi kapsamında değerlendirilmesi uygundur.

4. etkinlikte öğrencilere dört cümle parçası verilmiş ve onlardan bu cümleleri "Parktaki Bilim" metninden hareketle amaç- sonuç ve koşul- sonuç anlamı verecek şekilde tamamlamaları istenmiştir: "Salıncakta sallanmak için birinin sizi itmesi ya da kendinizi ayaklarınızla geriye doğru itmeniz gerekir" (amaç- sonuç), "Yüksekteki bir cismi bırakttğınızdaysa düşmeye başlar" (koşul- sonuç). Cümlede anlam konusu etrafinda şekillendirilen etkinliğin cümle bilgisi kapsamında ele alınması uygundur.

7. etkinliğin b basamağında yer alan "Yazma Becerisi Öz Değerlendirme Formu"nda yer alan maddelerden ikisini de cümle bilgisi açısından ele almak mümkündür: "Anlaml ve kurallı cümleler yazdım", "Hikâyemi zenginleştirmek için atasözleri, deyimler ve özdeyişler kullandım". Cümlelerden ilki anlamına ve yükleminin yerine göre cümle türleri, ikincisi ise birer cümle ya da sözcük grubu yapılanışında olabilen atasözü, deyim ve özdeyişlerle ilgilidir.

8. etkinlikte öğrencilere yedi cümle verilmiş ve onlardan bu cümlelerdeki nesnelerin altını çizmeleri ve türünü belirtmeleri istenmiştir: "Bu oyuncakların ișleyișini fizik kuralları açısından inceleyelim" (Belirtili nesne), "Öğretmenimiz 'Parktaki Bilim metnini okuyun' dedi" (Belirtisiz nesne). Cümlenin ögelerinden nesne ve türlerine odaklanılan etkinliğin bu açıdan cümle bilgisi kapsamında ele alınması mümkündür.

"Uzay Giysileri" dinleme/ izleme metninin 1. etkinliğinde öğrencilerden metni dinlerken not aldıkları sözcüklerin anlamını tahmin etmeleri, tahminlerini sözlük anlamı ile karşılaştırmaları ve sözcükleri anlamına uygun olarak birer cümlede kullanmaları istenmiştir. Sözcüklerin cümlede kullanılması süreçlerine yaslanan etkinliğin, bu açıdan cümle bilgisi kapsamında değerlendirilmesi mümkündür.

7. etkinlikte öğrencilere altı cümle verilmiș ve onlardan bu cümlelerdeki özne ve yüklemlerin altını çizmeleri, karşısındaki kutucuğa ise yer tamlayıcılarını yazmaları istenmiştir: "Bu giysi olmadan astronotlar (özne) uzay boşluğunda vürüvemezler (yüklem)", Uzay boşluğunda (yer tamlayıcısı). Cümlenin ögelerinden özne, yüklem ve yer tamlayıcısı üzerinde durulan etkinlik, bu açıdan cümle bilgisi kapsamında ele alınmaya uygundur.

“Tema Sonu Değerlendirme Çalışmaları” bölümünün 6. maddesinde öğrencilere üç cümle verilmiş ve onlardan bu cümleleri anlam ilişkilerine göre (neden- sonuç, amaç- sonuç, koşulsonuç) değerlendirmeleri istenmiştir: "Dağ geçitleri, dağları aşmak için kullanılır" (amaç- sonuç), "Kış aylarında aşılması zor olduğu için Zigana Dağları'na tünel inşa edilmiş" (neden- sonuç), "Tünel biterse ülkemizin en uzun tüneli olacak" (koşul- sonuç). Cümlede anlam ilişkileri üzerinde durulmuş olması, bu maddenin cümle bilgisi kapsamında ele alınmasını gerekli kılmaktadır.

7. maddede öğrencilere seçeneklerde verilen deyimlerin hangisinin "parasal yönden işini yoluna koymak" anlamında olduğu sorulmuştur: B) Belini doğrultmak. Sözcük grubu (isim- fiil grubu) yapılanışındaki bir deyimin anlamının sorgulandığı soru maddesinin bu açıdan cümle bilgisi kapsamında değerlendirilmesi mümkündür.

9. maddede öğrencilere seçeneklerde verilen cümlelerin hangisinde yer tamlayıcısı olmadığ1 sorulmuştur: "Serçeler, her zaman görebildiğimiz sevimli kuşlardır". Cümlenin ögelerinden yer tamlayıcısı üzerinde durulan madde, bu açıdan cümle bilgisi kapsamında değerlendirilmeye uygundur.

10. maddede öğrencilere "Çağın yeni hastalı̆̆l, sosyal medya bă̆ımlılığıdır” cümlesinin yüklemi sorulmuştur: sosyal medya bağımlllığıdır. Cümlenin ögelerinden yüklem konusuna ve 
sözcük gruplanın cümlenin ögelerinin bulunması süreçlerinde parçalanmaması kuralına yaslanan soru maddesi, bu açıdan cümle bilgisi kapsamında ele alınmaya uygundur.

\section{Tema: Birey ve Toplum}

Temada "Kaldırımlar" (Necip Fazıl Kısakürek, Şiir), "Portakal" (Mustafa Çiftçi, Hikâye), "Dilimiz Kuşatma Altında" (Deniz Banoğlu) başlıklarını taşıyan üç okuma; "Karanlığın Rengi Beyaz" (Kerim- Selim Altınok) başlı̆̆ını taşıyan bir dinleme/ izleme, "Masal Ağacı" (Gülten Dayığlu, Hikâye) başlı̆̆ını taşıyan bir serbest okuma metni olmak üzere toplam beş metin bulunmaktadır.

Tablo 4: 4. Temada Yer Alan Etkinliklerin Cümle Bilgisi Konularına Dağılımı

\begin{tabular}{|c|c|c|c|c|}
\hline \multicolumn{5}{|c|}{ 4. Tema: Birey ve Toplum } \\
\hline $\begin{array}{l}\text { Metinler } \\
\text { Cümle Bilgisi } \\
\text { Konularl }\end{array}$ & Kaldırımlar & Portakal & $\begin{array}{c}\text { Dilimiziz } \\
\text { Kuşatma } \\
\text { Altında }\end{array}$ & $\begin{array}{c}\text { Karanlığın Rengi } \\
\text { Beyaz }\end{array}$ \\
\hline Cümlede anlam & 4.a. Etkinlik & & & \\
\hline $\begin{array}{l}\text { Söz sanatlarının } \\
\text { cümle anlamına } \\
\text { katkıs1 }\end{array}$ & 4.b. Etkinlik & & & \\
\hline Cümlenin ögeleri & 6. Etkinlik & 7. Etkinlik & 7. Etkinlik & 6. Etkinlik \\
\hline $\begin{array}{l}\text { Sözcüklerin ve sözcük } \\
\text { gruplarının cümlede } \\
\text { kullanılması }\end{array}$ & & 1. Etkinlik & & \\
\hline $\begin{array}{l}\text { Cümlede ağır basan } \\
\text { duygu }\end{array}$ & & 2. $\quad$ Etkinlik & & \\
\hline $\begin{array}{l}\text { Anlamına göre cümle } \\
\text { türleri }\end{array}$ & & $\begin{array}{l}\text { 5. } \text { Etkinlik } \\
\text { 6.b.Etkinlik }\end{array}$ & 2. Etkinlik & \\
\hline $\begin{array}{l}\text { Yükleminin yerine } \\
\text { göre cümle türleri }\end{array}$ & & 6.b. Etkinlik & & \\
\hline $\begin{array}{l}\text { Sözcük grubu ya da } \\
\text { cümle yapılanışındaki } \\
\text { atasözü, deyim ve } \\
\text { özdeyişler }\end{array}$ & & 6.b. Etkinlik & & 5.b. Etkinlik \\
\hline $\begin{array}{l}\text { Sözcük grubunda } \\
\text { anlam }\end{array}$ & & & & 2. Etkinlik \\
\hline $\begin{array}{l}\text { Cümleler arası geçiş } \\
\text { ve bağlantı ifadeleri }\end{array}$ & & & & 5.b. Etkinlik \\
\hline
\end{tabular}

Tablo 4'te 4. temada yer alan metinlere yönelik oluşturulmuş etkinliklerin hangi cümle bilgisi konusu etrafında şekillendirildiği gösterilmektedir. Bu dağılım üzerine yapılan yorum ve değerlendirmeler, şu şekilde sıralanabilir:

"Kaldırımlar" metninin 4. etkinliğinin a basamağında öğrencilere şiirden seçilen dizeler verilmiş ve onlardan bu dizelerde yer alan söz sanatlarını cümlelerin karşılarındaki boşluklara yazmaları istenmiştir: "Evlerin bacasını kolluyor yıldırımlar" (Kişileştirme), "Biri benim, biri de serseri kaldırımlar" Karşılaştırma. Etkinliğin b basamağında ise öğrencilerden şiirde kullanılan söz sanatlarının anlatıma olan katkısını yazmaları istenmiștir: Anlatımı okuyucunun zihninde canlı kılmış, kalıcı yapmış, ilgi çekici hâle getirmiştir. Söz sanatlarının tespiti, cümle anlamının göz önünde bulundurulmasını gerekli kıldığından ve etkinliğin $b$ basamağında söz sanatlarının anlatıma olan katkısı sorgulandığından etkinliğin cümle bilgisi kapsamında ele alınması uygundur.

6. etkinlikte öğrencilere altı cümle verilmiş ve onlardan bu cümlelerde özne ve yüklemi belirlemeleri, zarf tamlayıcılarını da cümlelerin karşısındaki kutucuğa yazmaları istenmiştir: "(Ben/ Gizli Özne) arkama bakmadan yürüyorum (yüklem)" arkama bakmadan (zarf tamlayıc1s1). Cümlenin ögelerinden özne, yüklem ve zarf tamlayıcısı üzerinde durulan etkinliğin cümle bilgisi kapsamında değerlendirilmesi uygundur. 
"Portakal" metninin 1. etkinliğinde öğrencilere bazı sözcük ve sözcük gruplarının harfleri karışık olarak verilmiş ve onlardan bu harflerden, anlamı verilen ifadeleri oluşturup bunları bir de uygun biçimde cümlede kullanmaları istenmiştir. Verilen ifadelerden birinin sözcük grubu olması (mahcup etmek, isim- fiil grubu) ve bütün ifadelerin cümlede kullanılmasının istenmesi, bu etkinliğin cümle bilgisi kapsamında ele alınmasını gerekli kılmaktadır.

2. etkinliğin 6. sorusunda öğrencilere "Şimdi ne vakit portakal yesem elimi yıkamam, bir süre koklarım. Elif'i koklar gibi, anamı koklar gibi koklarım” cümlelerinde ağır basan duygunun ne olduğu sorulmuştur: Özlem. Cümlelerde ağır basan duygu konusu etrafında şekillenen etkinliğin cümle bilgisi kapsamında ele alınması uygundur.

5. etkinlikte öğrencilere Ali Canip Yöntem'in günlüğünden iki sayfa verilmiş ve onlardan bu günlüklere yönelik beş soru oluşturup arkadaşlarına sormaları istenmiştir. Soru cümleleri, anlamına göre cümle türlerinden biri olduğundan etkinlikte gerçekleştirilen sürecin cümle bilgisi kapsamında değerlendirilmesi uygundur.

6. etkinliğin b basamağında öğrencilere "Yazma Becerisi Öz Değerlendirme Formu" verilmiştir. Bu formun ilk iki maddesinin cümle bilgisi kapsamında ele alınması uygundur: "Yazımı anlamlı ve kurallı cümlelerle yazdım", "Yazımı zenginleştirmek için atasözleri, deyimler ve özdeyişler kullandım”. Maddelerden ilki, anlamına ve yükleminin yerine göre cümle türleri ile ikincisi ise birer sözcük grubu ya da cümle yapılanışında olabilecek atasözleri, deyimler ve özdeyiş̧ler ile bağlantılı olduğundan etkinliğin cümle bilgisi kapsamında ele alınması uygundur.

7. etkinlikte öğrencilere dokuz cümle verilmiş ve onlardan bu cümlelerde koyu yazılan sözcük ya da sözcük gruplarının cümlenin hangi ögesi olduğunu ilgili kutucuğa işaretlemeleri istenmiştir: "Her yerde ögrenci var"/ yer tamlayıcısı, "Portakalların hepsini yedirmedi annem"/ özne. Cümlenin ögeleri etrafında şekillendirilen etkinlik, bu açıdan cümle bilgisi kapsamında değerlendirilmeye uygundur.

"Dilimiz Kuşatma Altında" metninin 2. etkinliğinde öğrencilerden metin ile ilgili dört soru ile yanıtlarını hazırlayıp bu soruları arkadaşlarına yöneltmeleri istenmiştir. Soru cümleleri, anlamına göre cümle türlerinden biri olduğundan bu etkinliğin cümle bilgisi kapsamında ele alınması mümkündür.

7. etkinlikte öğrencilere yedi cümle verilmiş ve onlardan bu cümlelerin ögelerini bularak karşılarındaki öge dizilişleriyle eşleştirmeleri istenmiştir: "Hepimizin katkısıyla/ dilimiz/ giderek/ yozlaştırılıyor” D) Zarf T./ Özne/ Zarf T./ Yüklem. Cümlenin ögeleri konusu etrafında şekillenen etkinliğin bu açıdan cümle bilgisi kapsamında ele alınması uygundur.

"Karanlığın Rengi Beyaz" dinleme/ izleme metninin 2. etkinliğinin 6. sorusunda öğrencilere metinden hareketle "eğitimde firsat eşitliği" ifadesinden ne anladıkları sorulmuştur. Bağlamdan hareketle sözcük grubunun (kısaltma gruplarından bulunma grubu ve belirtisiz isim tamlaması) anlamının sorgulandığı maddenin cümle bilgisi kapsamında değerlendirilmesi mümkündür.

5. etkinliğin b basamağındaki "Yazma Becerisi Öz Değerlendirme Formu"nun 1 ve 3. maddeleri, "Yazımı zenginleştirmek için atasözü, deyim ve özdeyiş kullandım", "Yazımda uygun geçiş ve bağlantı ifadelerini (oysaki, özellikle, başka bir deyişle, kısaca, böylece, ilk olarak, son olarak...) kullandım" şeklindedir. Bu maddelerden ilki, birer sözcük grubu ya da cümle yapılanışında olabilecek atasözü, deyim ve özdeyişlerle, ikincisi ise cümleler arası türlü anlam ilişkileri kurulmasını sağlayan geçiş ve bağlantı ifadeleri ile ilgili olduğundan etkinliğin cümle bilgisi kapsamında ele alınması mümkündür.

6. etkinlikte öğrencilere on bir cümle verilmiş ve onlardan bu cümlelerde nesne, yer tamlayıcısı ve zarf tamlayıcılarını bularak kendilerine verilen tablonun uygun bölümüne yazmaları 
istenmiştir: "Kâğıda yazarken Selim'in yazısı satırlardan kayıyor" (Nesne yok, Yer Tamlayıcıs1 Yok, Zarf Tamlayıcısı: Kâğıda yazarken). Cümlenin ögelerinden nesne, yer tamlayıcısı ve zarf tamlayıcısı üzerinde durulan etkinliğin cümle bilgisi kapsamında değerlendirilmesi mümkündür.

“Tema Sonu Değerlendirme Çalışmaları” bölümünün 5. maddesinde öğrencilere beş cümle verilmiş ve onlardan bu cümlelerde koyu yazılan sözcük ya da sözcük gruplarının cümlenin hangi ögesi olduğunu verilen kutucuğun ilgili bölümüne (yüklem, özne, nesne, yer tamlayıcısı, zarf tamlayıc1s1) işaretlemeleri istenmiştir: Çocuk, adamın oturduğu banka doğru yürüdü/ Özne. Cümlenin ögeleri konusuna odaklanılan maddenin bu açıdan cümle bilgisi kapsamında ele alınması mümkündür.

6. maddede öğrencilere seçeneklerde verilen deyimlerden hangisinin, kullanıldığı cümleye uygun olmadığ sorulmuştur: İyi niyetli olduğundan burnundan kıl aldırmıyor. Sözcük grubu biçiminde yapılandırılmış bir deyimin (burnundan kıl aldırmamak, isim- fiil grubu) cümleye kattığ anlamın sorgulandığı bu soru maddesi, bu açıdan cümle bilgisi kapsamında değerlendirilmeye uygundur.

7. maddede öğrencilere dört cümleden kurulu k1sa bir metin verilmiş ve onlardan bu metinde numaralanmıș cümlelerin hangisinin kișisel düşünce içerdiği sorulmuştur: "Kalenin temelinin yalçın kaya üzerine kurulması akıllıca bir harekettir". Kanıtlanabilirlik açısından cümle türleri (öznel ve nesnel yargılı cümleler) konusu etrafinda şekillendirilen maddenin bu açıdan cümle bilgisi kapsamında ele alınması uygundur.

8. maddede öğrencilere "Kişsinin değerini, kadir ve knymetini en iyi bilenler; bu işle ilgili kimseler ile kendi çevresinde bulunanlardır. Bir insanı ve onun yaptıklarını yakın çevresi takdir eder" şeklinde açıklaması verilen atasözünün hangisi olduğu sorulmuştur: Taş yerinde ağırdır. Bir cümle yapılanışındaki atasözünün anlamının sorgulandığı maddenin bu açıdan cümle bilgisi kapsamında değerlendirilmesi uygundur.

10. maddede öğrencilere "Dün gecel apartman sakinleri/ sokakta bulduğu köpeği/ doyurdular" cümlesinin ögelerinin hangi seçenekte doğru sıralanmış olarak verildiği sorulmuştur: Zarf tamlayıcıs1/ Özne/ Belirtili nesne/ Yüklem. Verilen cümlenin ögelerinin tespit edilmesi süreci ile şekillendirilen soru maddesi, bu açıdan cümle bilgisi kapsamında ele alınmaya uygundur.

\section{Tema: Zaman ve Mekân}

Temada "Eşref Saat" (Şevket Rado, Sohbet), "Türkiye" (Attila İlhan, Şiir), "Peri Bacaları" (Yaşar Kemal) başlığını taşıyan üç okuma; "Robinson Crusoe" (Daniel Defoe) başlığını taşıyan bir dinleme/ izleme ile "İstanbul'la Hasbihâl" (Zeynel Beksaç, Şiir) başlığını taşıyan bir serbest okuma metni olmak üzere toplam beş metin bulunmaktadır. 
8. Sınıf Türkçe Ders Kitabındaki (MEB, 2019) Cümle Bilgisi Etkinliklerine Eleştirel Bir... 2585

Tablo 5: 5. Temada Yer Alan Etkinliklerin Cümle Bilgisi Konularına Dağılımı

\begin{tabular}{|c|c|c|c|c|}
\hline \multicolumn{5}{|c|}{ 5. Tema: Zaman ve Mekân } \\
\hline $\begin{array}{l}\text { Metinler } \\
\text { Cümle Bilgisi } \\
\text { Konuları }\end{array}$ & Eşref Saat & Türkiye & Peri Bacaları & $\begin{array}{c}\text { Robinson } \\
\text { Crusoe }\end{array}$ \\
\hline $\begin{array}{l}\text { Sözcüğün cümlede } \\
\text { kullanılmas }\end{array}$ & 1. Etkinlik & & & \\
\hline $\begin{array}{l}\text { Sözcük grubu } \\
\text { yapılanışındaki } \\
\text { deyimler }\end{array}$ & 2.a. Etkinlik & & & \\
\hline $\begin{array}{l}\text { Deyimlerin cümle } \\
\text { anlamına katkısı }\end{array}$ & 2.b. Etkinlik & & & \\
\hline $\begin{array}{l}\text { Kanıtlanabilirlik } \\
\text { açısından cümle } \\
\text { türleri }\end{array}$ & 5. Etkinlik & & 3. Etkinlik & \\
\hline Cümlenin ögeleri & 6.a.Etkinlik & & 6.a. Etkinlik & 7. Etkinlik \\
\hline $\begin{array}{l}\text { Öznesine göre fiil } \\
\text { çatıları }\end{array}$ & 6.b. Etkinlik & 6. Etkinlik & & \\
\hline $\begin{array}{l}\text { Nesnesine göre fiil } \\
\text { çatıları }\end{array}$ & & & $\begin{array}{l}\text { 6.b. Etkinlik } \\
\text { 7. Etkinlik }\end{array}$ & 7. Etkinlik \\
\hline Sözcük grupları & & 1. Etkinlik & 1. Etkinlik & \\
\hline $\begin{array}{l}\text { Söz sanatlarının } \\
\text { cümle anlamına } \\
\text { katkısı }\end{array}$ & & 4. Etkinlik & & \\
\hline $\begin{array}{l}\text { Anlamına göre } \\
\text { cümle türleri }\end{array}$ & & & 2. Etkinlik & \\
\hline $\begin{array}{l}\text { Cümleler arası } \\
\text { geçiş ve bağlantı } \\
\text { ifadeleri }\end{array}$ & & & 4. Etkinlik & \\
\hline $\begin{array}{l}\text { Fiillerin yüklem } \\
\text { görevinde cümlede } \\
\text { kullanılması }\end{array}$ & & & 7. Etkinlik & \\
\hline
\end{tabular}

Tablo 5'te 5. temada yer alan metinlere yönelik oluşturulmuş etkinliklerin hangi cümle bilgisi konusu etrafinda şekillendirildiği gösterilmektedir. Bu dağılım üzerine yapılan yorum ve değerlendirmeleri şu şekilde sıralamak mümkündür:

"Eşref Saat" metninin 1. etkinliğinde öğrencilere yedi sözcük verilmiş ve onlardan bu sözcükleri anlamları ile eşleştirmeleri, eşleştirmede açıkta kalan anlamı karşılayan sözcüğü bularak bir cümlede kullanmaları istenmiştir: "Esaret: Kölelik, tutsaklık, esirlik". Anlama karşılık gelen sözcüğün cümlede kullanılmasını gerekli kılan etkinliğin bu açıdan cümle bilgisi kapsamında ele alınması uygundur.

2. etkinliğin a basamağında öğrencilere beş cümle verilmiş ve onlardan bu cümlelerde geçen deyimlerin cümleye kattığı anlamları cümlelerin altına yazmalanı istenmiştir: iple çekmek, bam teline dokunmak, tereyağından kll çeker gibi. Etkinliğin b basamağında ise öğrencilerden deyimlerin anlatıma olan katkısını yazmaları istenmiştir. Birer sözcük grubu yapılanışındaki deyimler ile cümleye ve anlatıma olan katkılarının sorgulandığ 1 bu etkinlik, bu açıdan cümle bilgisi kapsamında ele alınmaya uygundur.

5. etkinlikte öğrencilerden metinden öznel ve nesnel anlatıma uygun cümleler bulup etkinlikte verilen boşluklara yazmaları istenmiştir. Öznel cümleler: "Şair tabiatlı olanlar, akşam saatlerini severler", "Milletlerin eșref saatlerini büyük dâhiler keșfeder", "Duvardaki saatleri yaylar işletiyorsa ev hayatındaki eşref saatleri de tatl dil işletir". Nesnel cümleler: "Muhakkak ki 
her şeyin bir zamanı vardır”. Kanıtlanabilirlik açısından cümle türleri etrafında şekillenen etkinliğin bu açıdan cümle bilgisi kapsamında değerlendirilmesi uygundur.

6. etkinliğin a basamağında öğrencilere sekiz cümle verilmiş ve onlardan bu cümleleri ögelerine ayırmaları istenmiştir: "(Ben/ Gizli özne)/ eşref saatlerini kollamanın sırlarından (Yer tamlayıcısı)/ bahsedeceğim (Yüklem)”, “Öğle vaktinin gelmesi (Sözde özne)/ iple çekilir (Yüklem)”. Etkinliğin $\mathrm{b}$ basamağında öğrencilerden a basamağında kendilerine verilen pembe kutudaki cümlelerin özneleri ile mavi kutudaki cümlelerin öznelerini işi, oluşu, hareketi yapma bakımından karşılaştırmaları istenmiştir: "Pembe renkli kutudaki cümlelerde işi, oluşu, hareketi yapan özneler açıkça belirtilmiştir", "Mavi renkli kutudaki cümlelerde işi, oluşu, hareketi yapan özneler açıkça belirtilmemiştir". Öznesine göre fiil çatılarından etken ve edilgen yapıdaki cümleler üzerinde durulan etkinlik, bu açıdan cümle bilgisi kapsamında ele alınmaya uygundur.

"Türkiye" metninin 1. etkinliğinde öğrencilere sekiz sözcük/ sözcük grubu verilmiş ve onlardan, öncelikle bu ifadelerin anlamını tahmin etmeleri ardından da bu tahminleri sözlük anlamları ile karşılaştırmaları istenmiş̧tir. Bu ifadelerden ikisi sözcük grubu yapılanışında (bağrı yanık, yükleme grubu; ferik elması, belirtisiz isim tamlaması) olduğundan bu etkinliğin cümle bilgisi kapsamında ele alınması mümkündür.

4. etkinlikte öğrencilerden şiirdeki söz sanatlarının (benzetme, kişileştirme, karşıtllk) geçtiği dizeleri yazmaları istenmiştir. Benzetme: "Bulut gibi köpürmüs topraktan bereketi", "Bir şarkı gibi dağdan denize yürümüş", "Batan güneş gibi bakır taşkömürü”, "Ve göğe kılı̧ gibi çekmiş minarelerini”, "Aladağlar, Toroslar dev gibi gövden”; Kişileştirme: "Pehlivan dağlarında şafaklar büyümüş", "Ve rüzgâra vermiş saçlarını nefti ormanlar", "Şehirler padişahı canım İstanbul”; Karşıtlık: "Türkiye, Türkiye çok gülmüş, çok ağlamış". Söz sanatlarının tespit edilmesi süreçlerinde dizelerdeki cümlelerin taşıdıkları anlam özelliklerinin dikkate alınması gerektiğinden bu etkinliğin cümle bilgisi kapsamında ele alınması mümkündür.

6. etkinlikte öğrencilere altı cümle verilmiş ve onlardan bu cümleleri özne- yüklem (etkenedilgen) ilişkisi bakımından incelemeleri, fiillerin bu açıdan taşıdıkları özellikleri cümlelerin karşısında yer alan bölüme yazmaları istenmiştir: "Bereket, topraktan bulut gibi köpürtülmüş", edilgen fiil. Öznesine göre fiil çatıları konusu etrafında şekillenen etkinliğin bu açıdan cümle bilgisi kapsamında değerlendirilmesi mümkündür.

"Peri Bacaları" metninin 1. etkinliğinde öğrencilere yedi sözcük/ sözcük grubu, harflerinden bazıları eksik olarak verilmiş ve onlardan etkinlikte verilen anlamlarına bakarak bu ifadeleri bulmaları ve boşluklara uygun harfleri yerleştirmeleri istenmiştir. Bu ifadelerden biri sözcük grubu yapılanışında olduğundan etkinliğin cümle bilgisi kapsamında ele alınması mümkündür: tetikte durmak, isim- fiil grubu.

2. etkinlikte öğrencilerden metinle ilgili dört soru ve yanıtlarını hazırlamaları ve bu soruları arkadaşlarına yöneltmeleri istenmiştir. Soru cümleleri, anlamına göre cümle türlerinden biri olduğundan bu etkinliğin cümle bilgisi kapsamında ele alınması mümkündür.

3. etkinlikte öğrencilerden metinde geçen öznel ve nesnel ifadeleri yazmaları istenmiştir. Öznel ifadeler: "Seyrederken bütün bunları, dünyayı unutuyorsun", "Zamanında buralar güzel bir ülkeymiş", "Bura halkının bir tek kaygısı varmış, o da ölümden...”. Nesnel ifadeler: "İkindiye doğru Mustafa'yla yola düşüp Göreme’ye geldik”, "Göreme, büyücek bir koyakta”, "Bu türlü biçimlere, türlü hareketlere halk burada türlü efsaneler yaratmıştır". Kanıtlanabilirlik açısından cümle türleri üzerinde durulan etkinliğin bu açıdan cümle bilgisi kapsamında değerlendirilmesi mümkündür.

4. etkinliğin b basamağında yer alan "Sözlü Sunum Becerisi Öz Değerlendirme Formu"nda yer alan ikinci maddenin -cümleler arası anlam ilişkisi kurulması süreçlerinde kullanılan- geçiş ve bağlantı ifadeleri etrafinda şekillendirildiği için cümle bilgisi kapsamında ele alınması mümkündür: 
“Konuşmamda 'oysaki, başka bir deyişle, özellikle, ilk olarak' gibi uygun geçiş ve bağlantı ifadelerini kullandım".

6. etkinliğin a basamağında öğrencilere dört cümle verilmiş ve onlardan bu cümleleri ögelerine ayırmaları istenmiștir: "Bacalar ormanı (Özne)/ alabildiğine (Zarf tümleci)/ uzuyor (Yüklem)". Etkinliğin b basamağında ise a basamağında yeșil ve sarı kutucukta verilen cümlelerin fiillerini nesne alma durumuna göre değerlendirmeleri istenmiştir: Yeșil renkli kutudaki cümlelerin fiilleri nesne alıyor: "Seyrederken dünyayı unutuyorsun", "Tepeye gelenleri seyrederlermiş". Sarı renkli kutudaki cümlelerin fiilleri nesne almiyor: "Bacalar ormanı alabildiğine uzuyor", "Şapka gibi başında kalmış". Nesnesine göre fiil çatıları (geçişli ve geçişsiz fiiller) üzerinde durulan etkinlik, bu açıdan cümle bilgisi kapsamında ele alınmaya uygundur.

7. etkinlikte öğrencilere dokuz fiil verilmiş ve onlardan bu fiilleri yüklem görevinde cümlede kullanmaları, fiillerin nesne alıp almadıklarını da etkinlikte verilen kutucuğa örnekteki gibi yazmaları istenmiştir: yarat-, "Halk burada türlü efsaneler yaratmış", türlü efsaneler: belirtisiz nesne; koş-, "Sabahın erken saatlerinde koştum”, nesne yok. Cümlenin ögelerinden yüklem ile nesnesine göre fiil çatıları etrafında şekillendirilen etkinliğin bu açıdan cümle bilgisi kapsamında ele alınması uygundur.

"Robinson Crusoe" dinleme/ izleme metninin 7. etkinliğinde öğrencilere yedi cümle verilmiş ve onlardan bu cümlelerin öznesini, yüklemini ve varsa nesnesini bulmaları ve cümleleri nesnesine göre inceleyerek bu açıdan taşıdıkları özellikleri etkinlikte kendilerine verilen kutucuğun ilgili bölümüne yazmaları istenmiştir: "Gemi (Özne)/ hızla karaya doğru/ sürükleniyordu (Yüklem)", nesnesine göre geçişsiz. Cümlenin ögelerinden özne, yüklem ve nesne ile nesnesine göre fiil çatıları etrafında şekillenen etkinliğin bu açıdan cümle bilgisi kapsamında ele alınması uygundur.

“Tema Sonu Değerlendirme Çalışmaları" bölümünün 6. maddesinde öğrencilere "vurmak" sözcügünün seçeneklerde verilen cümlelerin hangisinde "Kriz, kitap dünyasını da vurdu" cümlesindeki anlamıyla kullanıldığı sorulmuştur: "D) Avrupa'da yaşanan olaylar, ekonomik hayatı $v u r d u$ ". Verilen sözcüğün yüklem olarak çekimlendiğinde cümleye kattığı anlamın sorgulandığı soru maddesinin bu açıdan cümle bilgisi kapsamında değerlendirilmesi mümkündür.

9. maddede öğrencilere seçeneklerde verilen cümlelerden hangisinin yükleminin nesnesine göre diğerlerinden farklı olduğu sorulmuştur: "Yaz tatilinde Marmaris'e gittik" (nesnesine göre geçişsiz fiil; diğer seçeneklerde sunulan fiiller ise geçişlidir). Nesnesine göre fiil çatıları üzerinde durulan soru maddesinin, bu açıdan cümle bilgisi kapsamında ele alınması mümkündür.

10. maddede öğrencilere kırmızı (Giydiği ceketi çıkardı/ Etken), mor (Pasta, güzelce süslendil Edilgen), sarı (Ders programı hazırlandı/ Edilgen) ve yeşill (Seni gördügü̈me sevindim/ Etken) kutucuklarda dört cümle verilmiş ve onlardan edilgen fiillerin bulunduğu kutucukların kaldırılması durumunda geriye hangi renk kutucuklarla nasıl bir şekil oluşacağı sorulmuştur: geriye etken fiillerin yer aldığı kırmızı ve yeşil kutucuklar kalacaktır. Öznesine göre fiil çatıları etrafında şekillendirilen soru maddesinin, bu açıdan cümle bilgisi kapsamında değerlendirilmesi uygundur.

\section{Tema: Millî Kültürümüz}

Temada "Göç Destanı" (Derleyen: Nihat Sami Banarlı, Destan), "Vatan Sevgisini İçten Duyanlar" (Âşık Veysel Şatıroğlu, Şiir), "Bir Fincan Kahve" (Mehmet Önder) başlığını taşıyan üç okuma; "Kız Kulesi" (Mevlüt Kaplan) başlı̆̆ını taşıyan bir dinleme/ izleme ile "Karagöz" (Derleyen: Bekir Aktan) başlığını taşıyan bir serbest okuma metni olmak üzere toplam beş metin bulunmaktadır. 
Tablo 6: 6. Temada Yer Alan Etkinliklerin Cümle Bilgisi Konularına Dağılımı

\begin{tabular}{|c|c|c|c|c|}
\hline \multicolumn{5}{|c|}{ 6. Tema: Millî Kültürümüz } \\
\hline $\begin{array}{l}\text { Metinler } \\
\text { Cümle Bilgisi Konuları }\end{array}$ & Göç Destanı & $\begin{array}{c}\text { Vatan } \\
\text { Sevgisini } \\
\text { İçten } \\
\text { Duyanlar } \\
\end{array}$ & Bir Fincan Kahve & Kız Kulesi \\
\hline $\begin{array}{l}\text { Sözcüğün cümlede } \\
\text { kullanılmas1 }\end{array}$ & 1. Etkinlik & & & \\
\hline Sözcük grupları & 6. Etkinlik & & 1. Etkinlik & \\
\hline $\begin{array}{l}\text { Öznesine göre fiil } \\
\text { çatıları }\end{array}$ & 9. Etkinlik & & & \\
\hline $\begin{array}{l}\text { Nesnesine göre fiil } \\
\text { çatıları }\end{array}$ & 9. Etkinlik & & & \\
\hline $\begin{array}{l}\text { Cümleler arası geçiş ve } \\
\text { bağlantı ifadeleri }\end{array}$ & & $\begin{array}{l}\text { 7.b. } \\
\text { Etkinlik }\end{array}$ & & \\
\hline $\begin{array}{l}\text { Yükleminin türüne } \\
\text { göre cümle türleri }\end{array}$ & & $\begin{array}{l}10 . a . \\
\text { Etkinlik } \\
\text { 10.b. } \\
\text { Etkinlik } \\
\end{array}$ & & \\
\hline $\begin{array}{l}\text { Anlamına göre cümle } \\
\text { türleri }\end{array}$ & & & 3. Etkinlik & \\
\hline $\begin{array}{l}\text { Yükleminin yerine } \\
\text { göre cümle türleri }\end{array}$ & & & 6. Etkinlik & \\
\hline $\begin{array}{l}\text { Yapısı bakımından } \\
\text { cümle türleri }\end{array}$ & & & & $\begin{array}{l}\text { a. Etkinlik } \\
\text { b. Etkinlik }\end{array}$ \\
\hline
\end{tabular}

Tablo 6'da 6. temada yer alan metinlere yönelik olușturulmuş etkinliklerin hangi cümle bilgisi konusu etrafında şekillendirildiği gösterilmektedir. Bu dağılım üzerine yapılan yorum ve değerlendirmeler, şu şekilde sıralanabilir:

"Göç Destanı" metninin 1. etkinliğinde öğrencilere yedi sözcük verilmiş ve onlardan bu sözcükleri önce sözlük anlamlarıyla eşleştirmeleri, ardından da cümlede kullanmaları istenmiştir. Öğrenciler, anlamı verilmeyen sözcügün anlamını sözlükten bularak onu da cümlede kullanacaklardır: hakan, şölen, mukaddes, cenup, saadet, hadise, ehlî. Sözcüklerin cümlede kullanılması süreçleri ile şekillendirilen etkinliğin bu açıdan cümle bilgisi kapsamında ele alınması mümkündür.

6. etkinlikte öğrencilere "Nasrettin Hoca'nın Hayat Hikâyesi" metni verilmiş, onlardan bu metinde koyu ve farklı yazı karakteri ile yazılmıș sözcük ve sözcük gruplarını tespit etmeleri, yazı karakterlerinin bu şekilde kullanılma amacının ne olabileceğini yazmalanı istenmiştir: Nasreddin Hoca, Eskişehir, Sivrihisar, Hortu, Fuat Köprülü ve Pertev Naili Boratav, Sıdıka Hatun, Abdullah Efendi. Yazı karakterlerini bu şekilde kullanmanın amacı, okuyucunun dikkatini çekerek önemli bilgilerin akılda kalıcı olmasını sağlamaktır. Nasrettin Hoca, Sıdıka Hatun, Abdullah Efendi, unvan grubu (Karahan, 2018, s. 68- 69); Fuat Köprülü, Pertev Naili Boratav, birleşik isim grubu (Karahan, 2018, s. 69- 70) yapılanışında olduğundan bu etkinliğin cümle bilgisi kapsamında değerlendirilmesi uygundur.

9. etkinlikte öğrencilere dokuz cümle verilmiş ve onlardan bu cümlelerin öznesine ve nesnesine göre fiil çatıları açısından taşıdıkları özellikleri etkinlikte kendilerine verilen tablonun uygun bölümüne yazmaları istenmiştir: "A ğacın gövdesi yarılarak içinden beş çocuk çıktı”, özneyüklem ilişkisine göre etken, nesne- yüklem ilişkisine göre ise geçişsiz. Özne ve nesnesine göre fiil çatıları konusu etrafında şekillendirilen etkinliğin bu açıdan cümle bilgisi kapsamında ele alınması uygundur. 
"Vatan Sevgisini İçten Duyanlar" metninin 7. etkinliğinin a basamağında öğrencilere "Efemera" başlığını taşıyan bir metin verilmiş, b basamağında ise onlardan bu metindeki geçiş ve bağlantı ifadelerini bulmaları ve bu ifadelerin anlatıma olan katkısını belirtmeleri istenmiştir: "Başka bir deyişle, dolaylsı ile, kısaca". Bu ifadeler, metinde bir düşünce ile bu düşünceden doğan başka bir düşünce arasında bağlantı kurarlar. Düşünceyi olumlu ya da olumsuz olarak yönlendirirler. Geçiş ve bağlantı ifadelerinin tespit edilmesi ile anlatıma olan katkısının sorgulanması etrafinda şekillendirilen etkinliğin bu açıdan cümle bilgisi kapsamında değerlendirilmesi mümkündür.

10. etkinliğin a basamağında öğrencilere sekiz cümle verilmiş ve onlardan, önce bu cümlelerin yüklemlerini bulmaları; ardından da yükleminin türüne göre cümlenin türünü etkinlikte kendilerine verilen tablonun ilgili bölümüne yazmaları istenmiştir: "Gidiyorum (Yüklem) gündüz gece"/ Fiil cümlesi. Etkinliğin b basamağında da öğrencilerden isim ve fiil cümlelerine birer örnek yazmaları istenmiştir. Cümlenin ögelerinden yüklemin tespit edilmesi ile yükleminin türüne göre cümle türleri üzerinde durulan etkinliğin cümle bilgisi kapsamında ele alınması mümkündür.

"Bir Fincan Kahve" metninin 1. etkinliğinde öğrencilere sekiz sözcük/ sözcük grubu verilmiş ve onlardan bu yapıları, verilen anlamlarla eşleştirmeleri istenmiştir. Verilen ifadelerden biri, Farsça terkip/ isim tamlaması (ehlikeyif), diğeri isim-fiil grubu (türüm türüm tütmek) yapılanışında olduğundan bu etkinliğin cümle bilgisi kapsamında ele alınması mümkündür.

3. etkinlikte öğrencilere dört cümle verilmiş ve onlardan bu cümleleri koşul-sonuç ilişkisine göre metinden tamamlamaları istenmiştir: "Güney Anadolu'da ve Kıbrıs köylerinde kahvehaneye gelen konuk, önce selam verip kimin masasına oturmuşsa onun bir kahvesini içer". Anlamına göre cümle türlerinden koşul-sonuç cümleleri üzerinde durulan etkinlik, bu açıdan cümle bilgisi kapsamında ele alınmaya uygundur.

6. etkinlikte öğrencilere sekiz cümle verilmiş ve onlardan bu cümleleri yükleminin yeri bakımından değerlendirip ilgili kutucuğa işaretlemeleri istenmiştir: "Anadolu'nun geleneksel konukseverliği dillere destandır, dedik"/ Kurallı cümle, "İstanbul'un, Anadolu'nun günlük hayatına girmiş kahve"/ Devrik cümle. Yükleminin yeri bakımından cümle türleri üzerinde durulan etkinlik, bu açıdan cümle bilgisi kapsamında değerlendirilmeye uygundur.

"Kız Kulesi” dinleme/ izleme metninin 10. etkinliğinin a basamağında öğrencilere sekiz cümle verilmiş ve onlardan, bu cümleleri yapısına göre inceleyerek etkinlikte kendilerine verilen tabloda uygun kutucuğu işaretlemeleri istenmiştir: tek yüklemli cümle, fiilimsi bulunan cümle, birden çok yüklemli cümle, bağlacı olan cümle. "Falcılar, sırayla kralın kızının falına bakmışlar"/ Tek yüklemli cümle. Etkinliğin b basamağında öğrencilerin de bu cümle türlerine uygun birer örnek cümle yazmaları istenmiştir. Yapısı bakımından cümle türleri etrafında şekillendirilen bu etkinlik, cümle bilgisi kapsamında ele alınmaya uygundur.

"Tema Sonu Değerlendirme Çalışmaları” bölümünün 7. maddesinde öğrencilere seçeneklerde sunulan cümlelerden hangisinin devrik bir isim cümlesi olduğu sorulmuştur: " $C$ ) Çocuklardı bu hayatı güzel yapan". Yükleminin yerine ve türüne göre cümle türleri üzerinde durulan bu soru maddesi, bu açıdan cümle bilgisi kapsamında değerlendirilebilir.

8. maddede öğrencilere dört cümleden kurulu bir metin verilmiş ve onlardan, bu parçada numaralanmış cümlelerle ilgili seçeneklerde verilen ifadelerden hangisinin söylenemeyeceği sorulmuştur: "B) II numaralı cümle, birden çok yüklemi olan cümledir/ (II) Ebru sanatında kullanılan bütün malzeme ve araçlar ebrucu tarafindan hazırlanır"/ verilen bu cümle, tek yüklemlidir. Yapısı bakımından cümle türleri etrafında şekillendirilen soru maddesi, cümle bilgisi kapsamında ele alınmaya uygundur. 


\section{Tema: Doğa ve Evren}

Temada "Yılk1 Atı" (Abbas Sayar), "Rüzgâr" (Cahit Külebi), "Gündüzünü Kaybeden Kuş" (Halikarnas Balıkçısı) başı̆̆ğını taşıyan üç okuma; "Hava Kirliliği” başlığını taşıyan bir dinleme/ izleme, "Canberra" (Kanberra, Gülten Dayığlu) başlığını taşıyan bir serbest okuma metni olmak üzere toplam beş metin bulunmaktadır.

Tablo 7: 7. Temada Yer Alan Etkinliklerin Cümle Bilgisi Konularına Dağılımı

\begin{tabular}{|c|c|c|c|c|}
\hline \multicolumn{5}{|c|}{ 7. Tema: Doğa ve Evren } \\
\hline $\begin{array}{l}\text { Metinler } \\
\text { Cümle Bilgisi Konuları }\end{array}$ & Yılkı Atı & Rüzgâr & $\begin{array}{c}\text { Gündüzünü } \\
\text { Kaybeden Kuș }\end{array}$ & Hava Kirliliği \\
\hline $\begin{array}{l}\text { Söz sanatlarının cümle } \\
\text { anlamına katkısı }\end{array}$ & 7. Etkinlik & 4. Etkinlik & 4. Etkinlik & - \\
\hline $\begin{array}{l}\text { Anlamına göre cümle } \\
\text { türleri }\end{array}$ & 9. Etkinlik & & & - \\
\hline $\begin{array}{l}\text { Verilen sözcükleri } \\
\text { cümlede kullanarak şiir } \\
\text { yazma }\end{array}$ & & 7. Etkinlik & & - \\
\hline $\begin{array}{l}\text { Yükleminin türüne } \\
\text { göre cümle türleri }\end{array}$ & & 8. Etkinlik & & - \\
\hline $\begin{array}{l}\text { Yükleminin yerine } \\
\text { göre cümle türleri }\end{array}$ & & 8. Etkinlik & & - \\
\hline $\begin{array}{l}\text { Anlamına göre cümle } \\
\text { türleri }\end{array}$ & & 8. Etkinlik & & - \\
\hline $\begin{array}{l}\text { Yapısına göre cümle } \\
\text { türleri }\end{array}$ & & 8. Etkinlik & & - \\
\hline Sözcük grupları & & & 1. Etkinlik & - \\
\hline $\begin{array}{l}\text { Cümle düzeyinde } \\
\text { anlatım bozuklukları }\end{array}$ & & & 7. Etkinlik & - \\
\hline
\end{tabular}

Tablo 7'de 7. temada yer alan metinlere yönelik oluşturulmuş etkinliklerin hangi cümle bilgisi konusu etrafında şekillendirildiği gösterilmektedir. Bu dağılım üzerine yapılan yorum ve değerlendirmelerin şu şekilde sıralanması mümkündür:

"Yılk1 Atı" metninin 7. etkinliğinde öğrencilere beş cümle verilmiş ve onlardan, bu cümlelerde kişileştirilen varlıkları bulmaları istenmiştir: "Kar, ovaya doğru homurdana homurdana iniyordu"/ Kar, homurdanmak eylemi yüklenerek kişileştirilmiştir. Söz sanatlarının cümlenin anlamına katkısı üzerine şekillenen etkinlik, bu açıdan cümle bilgisi kapsamında değerlendirilmeye uygundur.

9. etkinlikte öğrencilere on iki cümle verilmiş ve onlardan, bu cümleleri anlamına göre incelemeleri ve verilen tabloda uygun kutucuğa işaretlemeleri istenmiştir: olumlu, olumsuz; olumlu soru, olumsuz soru. "Köyde klş, acı yüzünü göstermeye başlamıştır"/ Olumlu cümle. Anlamına göre cümle türleri üzerinde durulan etkinlik, bu açıdan cümle bilgisi kapsamında ele alınmaya uygundur.

"Rüzgâr" metninin 4. etkinliğinde öğrencilerden, şiirde kullanılan söz sanatlarını örnekteki gibi göstermeleri istenmiştir: "Köylere de uğradiysa ĕger/ Islak, karanlık odalarda beşik sallamıştır"/ Kişileştirme. Söz sanatlarının tespit edilmesi süreci, cümle anlamının göz önünde bulundurulmasını gerekli kıldığından bu etkinliğin cümle bilgisi kapsamında değerlendirilmesi uygundur.

7. etkinlikte öğrencilerden, verilen temalardan birini seçerek bir şiir yazmaları ve şiirlerine uygun bir başlık koymaları istenmiştir: güneş, yağmur, kar, bulut, rüzgâr, firtına. Şiir yazma ve içeriğine uygun başlığa karar verme işlemi; ses bilgisi, biçim bilgisi, anlam bilgisi, cümle bilgisi, 
estetik vb. disiplinlerin eşgüdümlü bir biçimde etkileşim hâlinde olduğu bir süreç olduğundan bu etkinliğin cümle bilgisi kapsamında ele alınması uygundur.

8. etkinlikte öğrencilere on cümle verilmiş ve onlardan, bu cümlelerin özelliklerini (yükleminin türüne, yükleminin yerine, anlamına ve yapısına göre) tespit ederek cümlelerin altına örnekteki gibi yazmaları istenmiştir: "Şimdi bir rüzgâr geçti buradan"/ Fiil cümlesi, devrik cümle, olumlu cümle, tek yüklemli cümle. Çeşitli ölçütler açısından cümle türleri üzerinde durulan etkinlik, bu açıdan cümle bilgisi kapsamında değerlendirilebilir.

"Gündüzünü Kaybeden Kuş" metninin 1. etkinliğinde öğrencilerden, anlamı verilen on sözcük/ sözcük grubunu bulmaları, bu ifadelerde boş bırakılan kutulara uygun harfleri yerleştirmeleri istenmiştir. Verilen ifadelerden ikisi, sözcük grubu yapılanışında olduğundan etkinliğin cümle bilgisi kapsamında ele alınması uygundur: tepetakla (birleşik sözcük), tan yeri (belirtisiz isim tamlamas1).

4. etkinlikte öğrencilere metinden seçilmiş altı cümle verilmiş ve onlardan, bu cümlelerde başvurulan söz sanatlarını belirleyerek örnekteki gibi yazmaları istenmiştir: "Denizin o hırlayan uçurumlarl, tepetakla dönmüş Niagara şelaleleri gibi havaya yükselirken onlara gün doğdu demektir"/ Benzetme. Söz sanatlarının tespit edilmesi süreci, cümle anlamının göz önünde bulundurulmasını gerekli kıldığından bu etkinlik, cümle bilgisi kapsamında ele alınabilir.

7. etkinlikte öğrencilere sekiz cümle verilmiş ve onlardan, bu cümlelerde yapılan anlatım bozukluklarını bulmaları ve cümlelerin düzeltilmiş biçimini örnekteki gibi yazmaları istenmiştir: "Kardeşime hiç klzmıyorum; çünkü çok seviyorum"/ "Kardeşime hiç klzmiyorum; çünkü onu çok seviyorum". Cümlede nesnenin eksik olmasından kaynaklanan anlatım bozuklukları üzerinde durulan etkinlik, bu açıdan cümle bilgisi kapsamında değerlendirilmeye uygundur.

"Hava Kirliliği” dinleme/ izleme metnine yönelik oluşturulmuş sekiz etkinlik arasında cümle bilgisi kapsamında ele alınmaya uygun bir etkinlik bulunmadığı tespit edilmiştir.

“Tema Sonu Değerlendirme Çalışmaları” bölümünün 2. maddesinde öğrencilerden, Abdurrahim Karakoç'un "Anadolu'da Bahar" şiirinde geçen "Gönül dile gelir kaval sesinde/ Boz martılar dügüun yapar Mersin'de" dizelerinden ne anladıklarını açıklamaları istenmiştir. Dizelere dağılan iki cümlenin, hem kendi anlamlarının hem de karşılıklı etkileşim sonucu kazandıkları anlam/lar/ın sorgulandığı bu soru maddesi, bu açıdan cümle bilgisi kapsamında değerlendirilmeye uygundur.

5. maddede öğrencilere dört cümle verilmiş ve onlardan, bu cümlelerden öznel olanların başına (Ö), nesnel olanlarınkine ise $(\mathrm{N})$ yazmaları istenmiştir: "(Ö) Türkiye'deki tatil; sadece manzaralar değil, unutulmaz deneyimlerdir", "(N) Türkiye, turizm pazarında, turist saylsı bakımından ilk on ülke içerisindedir". Kanıtlanabilirlik açısından cümle türleri etrafinda şekillenen bu soru maddesi, bu açıdan cümle bilgisi kapsamında ele alınmaya uygundur.

6. maddede öğrencilere "Kıs kapıya dayandı, daha kömür alamadık" cümlesinde koyu yazılan sözle ne anlatılmak istendiği sorulmuştur: gelip çatmak. Hem "kapıya dayanmak" ifadesi, isim- fiil grubu yapılanışında bir deyim (tdk.sozluk.gov.tr) olduğundan hem de bu ifadenin anlamını yansıtan yapılanış olan "gelip çatmak", isim- fiil grubu kuruluşunda bulunduğundan bu soru maddesinin cümle bilgisi kapsamında değerlendirilmesi uygundur.

8. maddede öğrencilere "Anlatılanlara göre oğlun çok hırslıymış" cümlesinin -sırasıylayükleminin türüne ve yerine, yapısına ve anlamına göre cümle türlerinden hangisine dâhil edilebileceği sorulmuştur: isim cümlesi, kurallı cümle, fiilimsi bulunan cümle, olumlu cümle. Farkl1 ölçütler açısından cümle türleri konusu etrafinda şekillendirilen bu soru maddesinin bu açıdan cümle bilgisi kapsamına dâhil edilmesi mümkündür. 
9. maddede öğrencilere Selim isimli bir öğrenciye ait olduğu belirtilen bir konuşma balonunda "Annemden ayrı kalamam ve sürekli ziyaret ederim" cümlesi verilmiş ve onlara bu cümledeki anlatım bozukluğunun nedeni sorulmuştur: nesne eksikliği, “... onu sürekli ziyaret ederim”. Cümle düzeyindeki anlatım bozukluklarının temel nedenleri etrafında şekillendirilen soru maddesi, bu açıdan cümle bilgisi kapsamında ele alınmaya uygundur.

\section{Tema: Vatandaşlık}

Temada "Haritada Bir Nokta" (Sait Faik Abasıyanık), "Yaşamaya Dair" (Nazım Hikmet Ran), "Kalbim Rumeli'de Kaldı" (Firdevs Tunçay) başlıklarını taşıyan üç okuma; "Zeytinyağı Üretimi" başlı̆̆ını taşıyan bir dinleme/ izleme ve "İmece" (Yaşar Kemal) başlı̆̆ını taşıyan bir serbest okuma metni olmak üzere toplam beş metin bulunmaktadır.

Tablo 8: 8. Temada Yer Alan Etkinliklerin Cümle Bilgisi Konularına Dağılımı

\begin{tabular}{lcccc}
\hline $\begin{array}{l}\text { Metinler } \\
\text { Cümle Bilgisi } \\
\text { Konuları }\end{array}$ & Haritada Bir Nokta & Yaşamaya Dair & $\begin{array}{c}\text { Kalbim } \\
\text { Rumeli'de } \\
\text { Kaldı }\end{array}$ & $\begin{array}{c}\text { Zeytinyağı } \\
\text { Üretimi }\end{array}$ \\
\hline $\begin{array}{l}\text { Cümle düzeyinde } \\
\text { anlatım bozuklukları }\end{array}$ & 8. Etkinlik & 6. Etkinlik & & \\
\hline $\begin{array}{l}\text { Şirde cümle anlamı } \\
\text { ve cümleler arası } \\
\text { anlam }\end{array}$ & 2. Etkinlik & & \\
\hline $\begin{array}{l}\text { Söz sanatlarının } \\
\text { cümle anlamına } \\
\text { katkıs1 }\end{array}$ & 4. Etkinlik & & \\
\hline $\begin{array}{l}\text { Anlamına göre cümle } \\
\text { türleri }\end{array}$ & & 2.Etkinlik & \\
\hline $\begin{array}{l}\text { Cümlede ağır basan } \\
\text { duygu }\end{array}$ & & & 7.Etkinlik & \\
\hline $\begin{array}{l}\text { Sözcüklerin cümlede } \\
\text { kullanılması }\end{array}$ & & & 1.Etkinlik \\
\hline
\end{tabular}

Tablo 8'de 8 . temada yer alan metinlere yönelik oluşturulmuş etkinliklerin hangi cümle bilgisi konusu etrafında şekillendirildiği gösterilmektedir. Bu dağılım üzerine yapılan yorum ve değerlendirmeler, şu şekilde sıralanabilir:

"Haritada Bir Nokta" metninin 8. etkinliğinde öğrencilere dokuz cümle verilmiş ve onlardan, bu cümlelerdeki anlatım bozukluklarını bulmaları ve cümlelerin doğru biçimlerini örnekteki gibi etkinlikte verilen boşluğa yazmaları istenmiştir: "Türkçe dersinde işaret ve belgisiz zamir konusunu işledik"/ "Türkçe dersinde işaret zamiri ve belgisiz zamir konusunu işledik". Cümle düzeyindeki anlatım bozuklukları konusu etrafında şekillendirilen etkinlik, bu açıdan cümle bilgisi kapsamında ele alınmaya uygundur.

"Yaşamaya Dair" metninin 2. etkinliğinin 2. sorusunda öğrencilere metinden alıntılanan "Bir sincap gibi mesela/ Yani, yaşamanın dışında ve ötesinde hiçbir şey beklemeden/ Yani bütün işin gücün yaşamak olacak" dizeleriyle şairin ne anlatmak istediği sorulmuştur. Dizelere dağılan cümlelerin hem kendi anlamları hem de birbirleri ile etkileşim kurarak kazandıkları anlam/lar etrafında şekillenen etkinlik, bu açıdan cümle bilgisi kapsamında değerlendirilmeye uygundur.

4. etkinlikte öğrencilerden, şiirde geçen söz sanatlarını bulmaları ve bu sanatların yer aldığı dizeleri yazmaları istenmiştir: "Bir sincap gibi mesela"/ Benzetme, "Mavi kadifede bir yaldız zerresi yani/ Yani bu koskocaman dünyamız"/ Karşıtlık, "Bu dünya soğuyacak günün birinde/ Hatta bir buz yığını"/ Abartma. Söz sanatlarının tespit edilmesi süreçleri, cümle anlamına yaslandığından bu etkinliğin cümle bilgisi kapsamında ele alınması uygundur. 
6. etkinlikte öğrencilere yedi cümleden oluşan bir metin verilmiş ve onlardan bu metinde geçen anlatım bozukluklarını bulmaları, onları düzelterek cümlelerin doğru biçimlerini defterlerine yazmaları istenmiştir: "Bugünkü düzeltmeyi ben, yarınki düzeltmeyi o yapacak diye anlaşmıştık"/ "Bugünkü düzeltmeyi ben yapacaktım, yarınki düzeltmeyi o yapacak diye anlaşmıştık". Cümle düzeyindeki anlatım bozuklukları etrafinda şekillenen etkinlik, bu açıdan cümle bilgisi kapsamında değerlendirilebilir.

“Kalbim Rumeli'de Kaldı" metninin 2. etkinliğinde öğrencilerden, metne yönelik üç soru hazırlayarak arkadaşlarına yöneltmeleri istenmiştir. Soru cümleleri, anlamına göre cümle türlerinden biri olduğundan bu etkinliğin cümle bilgisi kapsamında ele alınması uygundur.

7. etkinlikte öğrencilere yedi cümle verilmiş ve onlardan, bu cümleleri taşıdığ 1 duyguyla eşleştirmeleri, açıkta kalan duygu ile ilgili de bir cümle kurmaları istenmiştir: sevinç, sitem, özlem, beğenme, pişmanlık, küçümseme, üzüntü, şaşırma. "Ylllardır görmediğim kardeşim burnumda tütüyor"/ Özlem, "Keşke onun yanına hiç gitmeseydik"/ Pişmanlık; açıkta kalan duygu: beğenme. Cümlenin taşıdığı duygu üzerinde durulan ve açıkta kalan duygunun cümlede kullanılmasını gerekli kılan etkinlik, bu açıdan cümle bilgisi kapsamında değerlendirilmeye uygundur. Etkinlikte verilen bu cümlelerin, anlamına göre cümle türleri açısından incelendiklerinde yansıttıkları duygular bakımından ünlem cümleleri ile bağlantı kurularak ele alınmaları da mümkündür. Karahan; ünlemleri, ünlem gruplarını ve hitapları cümle çözümlemelerinin, cümlenin ögelerinin bulunması süreçlerinde 'cümle dışı öge' kapsamında ele almakta ve her cümlenin de yapısında bulunan kelime ve eklerin yönlendirdiği soru, bildirme, emir, istek, ünlem vb. anlam özelliklerinden birine sahip olduğunu belirtmektedir. Ancak Türkçede Sözdizimi kitabının cümlede anlam özelliklerine ayrılan bölümünde temel anlam özelliklerinden olmaları ve kullanım sıklığı dikkate alınarak sadece olumlu ve olumsuz cümlelerle soru cümleleri üzerinde durulduğunu ifade etmektedir (Karahan, 2018, s. 36- 38, 103). Karahan tarafindan cümlede 'temel anlam özellikleri' ve 'kullanım sıklığı' ölçüt alınarak ortaya konan bu veri, kabul edilmekle birlikte etkinlikte verilen cümlelerin -içlerinde herhangi bir ünlem ifadesi taşımamakla birlikte- belirli duyguları baskın olarak yansıttıklarından ünlem cümleleri kapsamında değerlendirilmesi teklif edilebilir.

“Zeytinyağı Üretimi” dinleme/ izleme metninin 1. etkinliğinde öğrencilerden, videoda geçen anlamını bilmedikleri sözcüklerin öncelikle anlamını tahmin etmeleri, ardından tahminlerini sözlük anlamlarıyla karşılaştırmaları ve her birini anlamlarına uygun biçimde cümlede kullanmaları istenmiştir. Anlamı araştırılan sözcüklerin cümlede kullanımını gerekli kılan etkinlik, bu açıdan cümle bilgisi kapsamında ele alınmaya uygundur.

"Tema Sonu Değerlendirme Çalışmaları" bölümünün 4. maddesinde öğrencilere "Demokratik prensibin en esasl unsuru, bütün milleti erkek ve kadının temsil etmesidir" cümlesinden ne anladıkları sorulmuştur. Cümlede anlam konusu üzerinde durulan soru maddesi, bu açıdan cümle bilgisi kapsamında değerlendirilmeye uygundur.

5. maddede öğrencilere üç cümle verilmiş ve onlardan, bu cümlelerin taşıdıkları anlam ilişkilerini (amaç-sonuç, koşul-sonuç, neden-sonuç) karşılarına yazmaları istenmiştir: "Devlet, toplumun düzenini sağlamak için kurallar koyar"/ Amaç-sonuç, "Vergimizi düzenli ödersek ülkemiz kalkınır"/ Koşul-sonuç, "Oğuz, 18 yaşını doldurduğu için seçme hakkına sahiptir"/ Nedensonuç. Cümleler arası anlam ilişkileri etrafında şekillenen soru maddesi, bu açıdan cümle bilgisi kapsamında ele alınmaya uygundur.

6. maddede öğrencilere beş cümle verilmiş ve onlardan, bu cümlelerin taşıdığı duyguları işaretlemeleri istenmiştir: "Köyümün yaylalar burnumda tütüyor"/ Özlem, "Böyle, ansızın gideceğini düşünmezdim"/ Şaşırma. Taşıdığ duygular açısından cümleler konusu etrafinda şekillenen soru maddesi, bu açıdan cümle bilgisi kapsamında değerlendirilmeye uygundur. 
8. maddede öğrencilere seçeneklerde verilen cümlelerden hangisinde "Yabancı dillerden alınmış, dilimize henüz yerleşmemiş kelimelerin Türkçesini kullanmalıyız" uyarısının dikkate alınmadığ1 sorulmuştur: “C) Yeni jenerasyon, teknolojik gelişmeleri çok iyi takip ediyor”. Cümlede dil bilinci etrafında şekillenen soru maddesi, cümle bilgisi kapsamında değerlendirilmeye uygundur.

9. maddede seçeneklerde verilen cümlelerden hangisinde bir anlatım bozukluğu olduğu sorulmuştur: "B) Büyüklerine değer verir, bayramlarda aramayl ihmal etmezdi"/ "Büyüklerine değer verir, bayramlarda onları aramayı ihmal etmezdi". Cümlede nesne eksikliğinden kaynaklı anlatım bozuklukları etrafında şekillenen soru maddesi, cümle bilgisi kapsamında ele alınmaya uygundur.

\section{Sonuç ve Öneriler}

Çalışmadan elde edilen veriler bir arada değerlendirildiğinde her bir temada yoğun olarak ele alınan ve etkinliklere yansitılan cümle bilgisi kapsamında değerlendirilebilecek konu başlıklarını şu şekilde sıralamak mümkündür:

1. temada; birer sözcük grubu yapılanışındaki deyimler ile cümle kuruluşundaki atasözleri ve özdeyişler ile bu ifadelerin anlamları ve cümlede kullanımları; kanıtlanabilirlik açısından cümle türleri; fiilimsi türleri ve ekleri, çekimli fiiller ile fiilimsiler arasındaki farklar; cümleler arası anlam ilişkileri (amaç-sonuç, neden-sonuç ve koşul-sonuç cümleleri), söz sanatlarının cümle anlamına katkısı, sözcük grupları (isim-fiil grupları), yüklem olan sözcügün cümleye kattığı anlam;

2. temada; düşünceyi geliştirme yolları (örneklendirme, benzetme, karşılaştırma); fiilimsi türleri ve ekleri, sözcük grupları (isim-fiil grubu, isim tamlaması) ve cümleye kattığı anlam, cümle kuruluşunda yapılandırılmış özdeyişler ve anlamları, birer sözcük grubu (isim-fiil grubu) yapılanışındaki deyimler ve cümlede kullanımı, işlenen metnin içeriğine göre soru cümlesi oluşturulması; okuma ve konuşma metinlerinde cümleler arası geçiş ve bağlantı ifadeleri ile bunların anlatıma olan katkısı, anlam ve söz sanatlarının cümle anlamına katkısı, cümleler arası anlam ilişkileri (neden-sonuç ilişkileri);

3. temada; metin içerisinde farklı yazı karakterleri ile yazılan sözcük grupları, cümlenin ögeleri (özne, nesne, yer tamlayıcısı ve yüklem), cümleler arası anlam ilişkilerinde kullanılan geçiş ve bağlantı ifadeleri, metnin içeriğine yönelik soru cümlesi oluşturulması, cümleler arası anlam ilişkileri (neden-sonuç, amaç-sonuç ve koşul-sonuç cümleleri), anlamına ve yükleminin yerine göre cümle türleri; cümle ya da sözcük grubu yapılanışındaki atasözü, deyim ve özdeyişler; dinleme/ izleme metninde anlamı bağlamdan tahmin edilen sözcüklerin cümlede kullanılması, sözcük grubu (isim-fiil grubu) yapılanışındaki deyimlerin, cümlenin anlamına katkısı;

4. temada; söz sanatlarının tespit edilmesi ve anlatıma olan katkısı, cümlenin ögeleri (özne, yüklem, yer tamlayıcısı, nesne, zarf), sözcüklerin/ sözcük gruplarının cümlede kullanılması, cümlede ağır basan duygu, metnin içeriğine yönelik soru cümlesi oluşturulması, anlamına ve yükleminin yerine göre cümle türleri; günlük tutarken atasözü, deyim ve özdeyişler kullanma; bağlamdan hareketle sözcük gruplarının anlamının tahmin edilmesi, yazma etkinliklerinde uygun geçiş ve bağlantı ifadelerinin kullanılması, sözcük grubu biçiminde yapılandırılmış deyim ve atasözlerinin cümle anlamına katkısı, kanıtlanabilirlik açısından cümle türleri;

5.temada; sözcüklerin cümlede kullanılması, sözcük grupları, sözcük grubu yapılanışındaki deyimlerin cümleye ve anlatıma katkısı, kanıtlanabilirlik açısından cümle türleri, cümlenin ögeleri, öznesine ve nesnesine göre fiil çatıları, şiirde söz sanatlarının geçtiği dizelerin tespit edilmesi; bazı harfleri eksik verilen sözcük gruplarının, etkinlikte verilen anlamlarından hareketle tahmin edilmesi; metnin içeriğine yönelik soru cümlesi oluşturulması, konuşma etkinliklerinde uygun geçiş ve bağlantı ifadelerinin kullanılması, çekimlenerek cümlenin yüklemi hâline getirilen fiilin cümleye kattığı anlam;

6. temada; sözcüklerin cümlede kullanılması, koyu ve farklı yazı karakteri ile dizilmiş sözcük gruplarının (unvan grubu, birleşik isim grubu) cümlenin ve metnin anlatımına olan katkısı, özne ve nesnesine göre fiil çatıları, geçiş ve bağlantı ifadelerinin anlatıma olan katkısı, cümlenin 
ögeleri; yapısına, yükleminin türüne ve yerine göre cümle türleri; sözcük gruplarının (isim tamlaması, isim-fiil grubu) anlamlarıyla eşleştirilmesi, cümleler arası anlam ilişkileri (koşul-sonuç cümleleri);

7. temada; söz sanatlarının tespit edilmesi ve cümle anlamına katkısı, anlamına göre cümle türleri, verilen temaya uygun şiir yazma ve şiirin içeriğine uygun başlık bulma; yükleminin türüne ve yerine, anlamına ve yapısına göre cümle türleri; harflerinden bazıları eksik verilen sözcük gruplarını etkinlikte verilen anlamlarından hareketle tahmin etme, cümle düzeyinde anlatım bozukluklarının tespit edilmesi ve düzeltilmesi, cümlede anlam, kanıtlanabilirlik açısından cümle türleri, sözcük grubu yapılanışındaki deyimlerin cümlede taşıdığı anlam;

8. temada; cümle düzeyinde anlatım bozuklukları ve düzeltilmesi, cümlede ve cümleler arasında anlam, söz sanatlarının tespit edilmesi ve cümle anlamına katkısı, metnin içeriğine yönelik soru cümlesi oluşturulması, cümlenin taşıdığı duygunun tespit edilmesi, sözcüğün cümlede kullanılması, cümleler arası anlam ilişkileri (amaç-sonuç, koşul-sonuç ve neden-sonuç cümleleri), çekimlenerek yüklem hâline getirilen fiillerin cümleye kattığı anlam, dil bilinci etrafında şekillendirilen cümleler konuları etrafında şekillendirilen etkinlik ve soru maddelerinin cümle bilgisi kapsamında ele alınması mümkündür.

MEB ve Dörtel Yayıncılık tarafından 2017'de yayımlanan 8. sınıfa yönelik oluşturulmuş iki Türkçe ders kitabındaki cümle bilgisine yönelik bütün etkinlikler, Durmuş tarafından bu çalışma ile benzer biçimde tespit edilerek çözümlenip yorumlanmıştır (Durmuş, 2020a; Durmuş, 2020b). Her iki kitapta da bu çalışmada ele alınan ders kitabından farklı olarak altı tema yer almakta, Türkçe dersleri de Ders (MEB, 2017a; Dörtel Yayınları, 2017a), Öğrenci Çalışma (MEB, 2017b; Dörtel Yayınları, 2017b) ve Öğretmen Kılavuz Kitabı (MEB, 2017c; Dörtel Yayınları, 2017c) olmak üzere üç kitap üzerinden yürütülmektedir.

MEB tarafindan yayımlanan kitaplar üzerine gerçekleştirilen çalışma sonunda incelenen kitaplarda cümlenin ana ve yardımcı ögeleri; anlamına (olumlu, olumsuz, soru), yükleminin yerine (kurall1, devrik), türüne (isim ve fiil cümlesi) ve yapısına (tek yüklemli, çok yüklemli, fiilimsi bulunan, bağlaç bulunan) göre cümle çeşitleri; sözcük grupları (isim tamlamaları, sıfat tamlamaları, fiilimsiler ve fiilimsi grupları vb.); birer sözcük grubu ya da cümle yapılanışında değerlendirilebilecek deyimler, atasözleri ve kalıp sözler; öznesine (etken, edilgen) ve nesnesine (geçişli, geçişsiz) göre fiil çatıları, cümle vurgusu, cümle uzunluğu, cümlede yüklem sayısı; cümlede anlam (olumlu, olumsuz, soru, varsayım, ihtimal, karşılaştırma, öneri, öznel ve nesnel yargı, amaç-sonuç, sebep-sonuç) ve duygu (sitem, özlem, üzülme, pişmanlık, abartma, şaşırma, beğenme); anlatım bozuklukları vb. konuları etrafında şekillenen etkinliklerin cümle bilgisi alanı açısından geniş bir yelpazeye yayıldığı tespit edilmiştir (Durmuş, 2020a, s. 1103).

Dörtel Yayınları tarafindan yayımlanan kitaplar üzerine gerçekleştirilen çalışmada ulaşılan sonuç ise incelenen kitaplarda sözcük grupları (isim tamlamaları, sıfat tamlamaları, fiilimsiler ve fiilimsi grupları vb.); birer sözcük grubu ya da cümle yapılanışında değerlendirilebilecek deyimler, atasözleri ve kalıp sözler; cümlede anlam (olumlu, olumsuz, soru, varsayım, ihtimal, karşılaştırma, öneri, öznel ve nesnel yarg1; amaç-sonuç ve sebep-sonuç cümleleri) ve duygu (sitem, özlem, üzülme, pişmanlık, abartma, şaşırma, beğenme), cümlenin ana ve yardımcı ögeleri; anlamına (olumlu, olumsuz, soru), yükleminin yerine (kurallı, devrik), türüne (isim ve fiil cümlesi) ve yapısına (tek yüklemli, çok yüklemli, fiilimsi bulunan, bağlaç bulunan) göre cümle çeşitleri; öznesine (etken, edilgen) ve nesnesine (geçişli, geçişsiz) göre fiil çatıları, cümle vurgusu, cümle uzunluğu, cümlede yüklem sayısı, anlatım bozuklukları vb. konuları etrafında şekillenen etkinliklerin tespit edildiği yönündedir (Durmuş, 2020b, s. 1753).

Karahan, Türkçede birleşik cümle problemi ve yapı bakımından cümle sınıflandırmaları üzerinde durduğu çalışmalarında tek yargılı her cümlenin basit cümle olduğu, isim-fiil, sıfat-fiil ve zarf-fiillerin diğer isim, sıfat ve zarflardan görev bakımından hiçbir farkları olmadığı ve bu kelimelerin varlığının basit cümlenin yapısını etkilemediği sonucuna ulaşmıştır (Karahan, 2011, s. 
235). Cümle, yüklem üzerine kurulur ve onun etrafinda genişler. Unsurlar, yapıları ne olursa olsun -kelime, kelime grubu veya cümle- yüklemin tamamlayıcısıdır ve isim değerindedir. Yine Karahan tarafından yapılan bir başka tespite göre 've, ki' vb. edatlarla birbirine bağlı yapılar; birer 'cümle' değil, 'cümleler topluluğu'dur: "Ayşse, çok çalıştı ve sınıfinı geçti”", "Ayşse, öyle çalıştı ki sınıfinı geçti" (Karahan, 2011, s. 240- 241). Bu verilerin, yapılandırmacı yaklaşım merkezli sezdirme yöntemi ile dilbilgisi öğretimi sürecinin altı temel basamağı esas alınarak tasarlanmış süreç temelli etkinliklerle Türkçe ders kitaplarına öğrenci düzeyi de göz önünde bulundurularak kademeli bir biçimde yansıtılması gerektiği belirtilebilir.

Sağır ve Demir Atalay, cümle bilgisi öğretimi sürecinin dört aşamadan oluşan bir yolla gerçekleştirilmesi gerektiğini ortaya koyarlar: I. Cümledeki kelime öbekleri/ sözcük grupları, isimleriyle tanınmalı ve belirtilmelidir; II. Cümle birden çok basit ya da birleşik cümleden oluşuyorsa "sıralı" ya da "bağlı" cümle dedikten sonra her bir basit ya da birleşik cümle, ayrı ayrı (...) çözümlenmelidir: III. Cümleyi oluşturan her bir kurucu, görev ismi ile; yüklem, özne, dolaylı tümleç, nesne, zarf tümleci olarak belirtilmelidir. IV. Cümlenin, yükleminin çeşidi bakımından fiil cümlesi mi, isim cümlesi mi; yükleminin yeri bakımından devrik cümle mi, kurallı cümle mi; anlamı bakımından olumlu cümle mi, olumsuz cümle mi, soru cümlesi mi, ünlem cümlesi mi; yapısı bakımından da basit yapılı mı, birleşik yapılı mı olduğu belirtilmelidir (Sağır ve Demir Atalay, 2016, s. 82).

Aslan'a göre dil bilgisi konuları (önad, adıl, belirteç, eylemsiler vb.), o konuya ilişkin kuru bilgiler biçiminde anlatılmamalı; yaklaşım, kuralı derste işlenen metindeki örnekler yoluyla sezdirmek, öğrencinin buradan hareketle anlama ve tanıma ulaşmasını sağlamak olmalıdır. Çocuk; öğretime kendi öznelliğiyle, özgünlüğüyle, istek ve edimleriyle katılmalıdır. Bu süreçte çocuğun her konuya olduğu gibi dil bilgisi konu alanına da eleştirel bakması, öğrenmeyi sorgulaması ve bu konuyu öğrenmenin kendisine ne gibi katkılar sağlayacağını bilmesi gereklidir. Cümle bilgisi konularının, örneğin fiilimsilerin öğretilmesi sürecinde öğretimin amacına ulaşabilmesi yani öğrencinin fiilimsileri doğru, yerinde ve işlevsel kullanabilmesi için öncelikle fiilimsilerin sıcça ve etkili kullanıldığı, çocuğun yaş ve gelişim düzeyine uygun nitelikli bir metnin seçilmesi ön koşuldur. Metni okuma ve anlamlandırma çalışmalarının ardından öğretmenin öğrencilerini $b u$ yapıların metne neler kattığı, ne gibi işlevler üstlendiği üzerine düşündürmesi gerekir. Bir sonraki adımda öğrencilere fiilimsilerin metinden kaldırıldı ̆̆ durumda olabilecek/ karşılaşılabilecek sorunlar, örnekler yoluyla gösterilmelidir. Bütün bu çalışmaların sonunda fiilimsilerin önemi ve işlevi, iyi öğrenildiği durumda anlama ve anlatma becerilerine olabilecek katkılar öğrencilerle birlikte ortaya konulmalı ve bu yolda kurallara ulaşılmaya çalışılmalıdır: fiilimsiler konusu iyi öğrenildiği takdirde daha uzun, daha güzel, daha sanatsal cümleler kurulabileceği, gereksiz sözcük tekrarları yapılmayacağı gibi. Üzerinde durulan her konu, nitelikli başka metinler üzerinde yürütülen ek çalışmalarla pekiştirilmelidir. $\mathrm{Bu}$ sürecin her basamağında öğretmen, kurallara ögrencinin ulaşmasını sağlayacak çalışmalar yaptırmalı, onu konunun önemine ve gerekliliğine ikna etmeli, onlara bu konuyu öğrenmenin anlama ve anlatma becerilerine ne gibi katkilar sağlayacă̆ını açıklamalıdır. Dil bilgisi ve onun bir alt alanı olan cümle bilgisi öğretimi; yaratıcı, düşündürücü, dönüştürücü ve üretken olmalıdır. Bilginin günlük yaşamında ne işe yarayacağ 1 , ona neler sağlayacağı, çocuğun bilmesi gereken bir konudur. Yığma bilgileri, edilgin biçimde dinleyen çocuğa aktarmanın çocuğun özerk birey olmasına hiçbir katkısı yoktur (Aslan, 2017, s. 30- 33).

Güneș tarafından belirtildiğine göre dünyada çoğu ülkede dil öğretiminde yapılandırmacı yaklaşım uygulanmaktadır. Bu yaklaşım gereği dil bilgisi öğretiminde yeni dil bilgisi, beceri ve etkinlik yaklaşımı, tümevarım modeli ve sezdirme yöntemi kullanılmaktadır. Dil bilgisi; ayrı bir ders olarak değil, dil öğrenme alanlarının içinde ele alınmaktadır. Sezdirme yöntemiyle dilin soyut kurallarını ezberlemeye değil, öğrencinin dil ve zihinsel becerilerini geliştirmeye ağırlık verilmekte; dil kurallarını bilimsel bilgiler gibi çeşitli deneysel etkinliklerle keşfederek öğrenmeleri amaçlanmakta; dilin işlev ve kuralları ile mantığını iyi öğrenerek bunları okuma ve yazma çalışmalarında kullanmaları öngörülmektedir. Sezdirme yöntemiyle dil bilgisi öğretimi; sunuş, 
olayı gözleme, kural ve hipotez oluşturma, alıştırma yapma ve uygulamaya aktarma olmak üzere altı aşamada gerçekleştirilmektedir (Güneş, 2013c, s. 171):

Sunuş basamağında öğretmen; öğrenciler ile birlikte dil bilgisi olaylarını çeşitli sorularla incelemekte, olayla ilgili yazım ve düzeltmeler yapmakta ve yaptırmakta, anlama sorunlarını tartışarak öğrencilerin dil bilgisinin önemini anlamalarını sağlamakta, ele alınan dil bilgisi olayıyla ilgili öğrencilerin ön bilgilerini harekete geçirmektedir (Güneş, 2013c, s. 180, 183).

Olayı gözlemleme basamağında öğrencileri okudukları metinlerdeki dil bilgisi kavramını tanımaya ve olayları gözlemlemeye davet eder (Güneş, 2013c, s. 180, 183).

Örnekleri değiştirme ve hipotez oluşturma basamağında öğrencilerden kendi ölçütlerine göre sınıflama yapmalarını ister, onların kullandıkları süreçleri gözlemler ve not eder, onları olayın işlevleri hakkında hipotezler oluşturmaya davet eder, oluşturulan hipotezleri öğrencilerle tartışır, ihtiyaca göre gerekli dil bilgisi değişimlerini açıklayıcı biçimde öğretir (Güneş, 2013c, s. 181, 183).

Hipotezleri doğrulama basamağında öğrencileri hipotezlerinin başka metinlerde uygulanabilirliğini doğrulamak için uygun dil değişimlerini kullanmaya davet eder (Güneş, 2013c, s. 181, 183).

Kural oluşturma basamağında öğrencilerden kesin kurallar oluşturmalarını, onları kaynak dil bilgisi kitaplarında inceleme ve değerlendirme yapmalarını ister (Güneş, 2013c, s. 181, 183).

Alıştırma yapma basamağında etkinlikler planlar ve öğrencilerin yeni bilgileri öğrenmeleri için bu etkinlikleri onlara verir (Güneş, 2013c, s. 182- 183).

Uygulamaya aktarma basamağında ise metin yazım sürecinde öğrenilenleri geliştirmek için olayı kontrol eder (Güneş, 2013c, s. 182- 183).

Tüm bu söylenilenler bir arada değerlendirildiğinde incelenen 8. Sinıf Türkçe Ders Kitabı'nda (MEB, 2019) yer alan cümle bilgisi etkinliklerinin cümle bilgisi alanına dâhil edilebilecek konu kapsamı açısından geniş yelpazeye yayılmış bir çeşitlilik gösterdiği, ancak gelecekte hazırlanacak kitapların başta Sağır ve Demir Atalay (2016) ve Aslan (2017) tarafından ortaya konulan görüşler ile özellikle Güneş (2013a, 2013b, 2013c) tarafından basamakları hakkında etraflıca bilgi verilen sezdirme yöntemi ile dil bilgisi öğretimi sürecinin altı temel basamağı dikkate alınarak düzenlenecek etkinliklerle güncellenmesi ve zenginleştirilmesi gerektiği belirtilebilir.

\section{Kaynakça}

Aksan, D. (1995). Şiir dili ve Türk şiir dili (dilbilim açısından bakış). Engin Yayınevi.

Aksan, D. (1974). Dilbilim açısından şiir. Türk Dili Dil ve Edebiyat Dergisi, XXIX(271), 558-573.

Aslan, C. (2017). Örnek eğitim durumlarlyla Türkçe- Türk dili ve edebiyatı öğretimi. Anı Yayınc1lk. https://doi.org/10.1501/egifak_0000001077

Büyüköztürk, Ş.; Akgün, Ö. E.; Karadeniz, Ş.; Demirel, F.; Kılıç Çakmak, E. (2010). Bilimsel araştırma yöntemleri. Pegem Akademi Yayınları. https://doi.org/10.14527/9789944919289

Çepni, S. (2009). Araştırma ve proje çalışmalarına giriş (4. bas.). Erol Ofset.

Durmuş, G. (2020a). 8. sınıf Türkçe ders kitabındaki (MEB, 2017) cümle bilgisi etkinliklerine eleştirel bir bakış. Turkish Studies- Social, 15(3), 1101-1126. https://dx.doi.org/10.29228/TurkishStudies.41500. 
Durmuş, G. (2020b). 8. sınıf Türkçe ders kitabında (Dörtel Yayıncılık, 2017) yer alan cümle bilgisi etkinlikleri üzerine bir değerlendirme. Turkish Studies- Education, 15(3), 1751-1785. https://dx.doi.org/10.29228/TurkishStudies.42080.

Ercilasun, A. B. (2010). Türkçede genel anlatım bozuklukları. İçinde Z. Korkmaz (Editör), Türk Dili ve Kompozisyon (ss. 287- 297). Ekin Yayınları.

Ergin, M. (2013). Türk dil bilgisi. Bayrak Yayınları.

Eselioğlu, H.; Set, S.; Yücel, A.; (2019). Ortaokul ve imam hatip ortaokulu Türkçe 8 ders kitabı. MEB Yayınları Devlet Kitapları Bilnet Matbaacılık.

Göğüş, B. (1978). Orta dereceli okullarımızda Türkçe ve yazın eğitimi. Gül Yayınevi.

Güneş, F. (2013a). Türkçe öğretimi yaklaşımlar ve modeller. Pegem Akademi Yayınları. https://doi.org/10.14527/9786053644927

Güneş, F. (2013b). Türkçede metin öğretimi yerine metinle öğrenme. Adlyaman Üniversitesi Sosyal Bilimler Enstitüsü Dergisi Türkçenin Eğitimi Öğretimi Özel Sayısl, 6(11), 603- 637. https://doi.org/10.14520/adyusbd.454

Güneş, F. (2013c). Yapılandırmacı yaklaşımla dil bilgisi öğretimi. Eğitimde Kuram ve Uygulama Journal of Theory and Practice in Education, 9(3), 171- 187.

Karadüz, A. (2009). Dil bilgisi öğretimi. İçinde A. Kırkkılıç \& H. Akyol (Editörler), İlköğretimde Türkçe öğretimi (ss. 285- 318). Pegem Akademi Yayınları. https://doi.org/10.14527/9786053645269.15

Karahan, L. (2018). Türkçede söz dizimi (25. Bas.). Akçağ Yayınları.

Karahan, L. (2011). Türk dili üzerine incelemeler. Akçă̆ Yayınları.

Karaörs, M. M. (1993). Türkçenin söz dizimi ve cümle tahlilleri. Erciyes Üniversitesi Matbaası.

Karasar, N. (1994). Bilimsel araştırma yöntemi. 3A Araştırma Eğitim Danışmanlık Ltd.

Korkmaz, Z. (2014). Türkiye Türkçesi grameri/ şekil bilgisi (4. Bas.). Türk Dil Kurumu Yayınları. https://doi.org/10.29000/rumelide.336587

MEB, (2019). Türkçe dersi ögrretim programı (ilkokul ve ortaokul 1, 2, 3, 4, 5, 6, 7 ve 8. sinıflar). MEB Yayınlar1. https://doi.org/10.14527/9786058008915.10

Sağır, M.; Demir Atalay, T. (2016). Yeni programa uygun etkinliklerle dil bilgisi öğretimi. Pegem Akademi Yayınları. https://doi.org/10.14527/9786053183259

Türk Dil Kurumu Yayınları. (t.y.). Kapıya dayanmak. İçinde Atasözleri ve deyimler sözlü̆̆̈̈, Şubat 24, 2020; tdk.sozluk.gov.tr

Zülfikar, H. (2010). Türkçede cümle. İçinde Z. Korkmaz (Editör), Türk Dili ve Kompozisyon (ss. 201- 261). Ekin Yayınları. 